\title{
Chapter 1: Activités de Surface
}

\section{The Circumstances of the Departure for the USA}

After the end of World War II, Czesław Miłosz made efforts to obtain a post in the diplomatic service abroad. At the time, diplomatic assignments were not uncommon among Polish writers. Those who accepted one included Julian Przyboś, Tadeusz Breza, Stanisław Jerzy Lec, Ksawery Pruszyński, Jerzy Zagórski, Antoni Słonimski, and Andrzej Kuśniewicz. Miłosz wanted to remain in Europe - he asked for this in a letter to the Ministry of Foreign Affairs of August 20, 1945: "I kindly request that I be enrolled as an employee of the Ministry, and that I be assigned to the Polish unit in Switzerland." 8 The poet signed a contract as a Ministry of Foreign Affairs employee on November 22, 1945. He was initially assigned to work in Canada - on September 26, the Ministry received a letter recommending him as the press attaché. ${ }^{9}$ Soon, however, he was reassigned to Chicago. ${ }^{10}$

\section{In London}

Miłosz and his wife Janina left Poland in December $1945 .{ }^{11}$ The journey went by plane from Warsaw to London, and then by sea to New York. In London, the

\footnotetext{
8 Czestaw Mitosz's Personnel File. Archive of the Ministry of Foreign Affairs, B 50 37/07 bundle 4. Miłosz, Czesław 8026, p. 1 (further quoted as Czesław Miłosz's Personnel File, page number). Indeed, efforts were made to have the poet to posted in Switzerland. In this matter, Jerzy Putrament sent a letter dated August 22, 1945 in which he wrote, among other things: "Honorable Citizen Minister! I would like to ask your permission to allocate Czesław Miłosz to the Swiss facility, as I know him well and could use him best there. I think that he could hold the post of second secretary to one of the attachés. He is undoubtedly a very capable man - probably also in diplomacy - the point is to put for him to appropriate use." Czesław Miłosz's Personnel File, p. 6. Emil Pasierski points out the instrumental role of Jerzy Borejsza in all this in his book Miłosz and Putrament. Lives in Parallel, Warsaw, 2011, p. 181. After the Nobel Prize for Literature was awarded to Miłosz, Putrament reminisces: "At that time, in 1945, Miłosz wanted to travel abroad. And he was smooth as silk to me. He insisted on a meeting with me. (...) Miłosz fawned over me because he wanted to obtain to the posting. And I arranged it for him - the trip to the States." "The first reaction to Miłosz was to abandon the poems...," Poezja 1981, no. 5/6, p. 79. In their turn, Miłosz's accounts from those years diverge rather significantly from those put forward by Putrament.

9 See Czesław Miłosz's Personnel File, p. 7.

10 As early as October 1946, when Miłosz was appointed cultural attaché and assigned to work at the Polish Embassy in Washington, he was formally referred to as a "contractual employee in Chicago, temporarily in New York" (Czesław Mitosz's Personnel File, p. 12).

11 Andrzej Franaszek gives December 4, 1945 as the date of the Miłoszes' departure from Warsaw. See also Franaszek's Miłosz. Biography. Edited and translated by Aleksandra and Michael Parker,
} 
Miłoszes stayed at the Esplanade Hotel, 2 Warrington Crescent. They spent about 5 weeks there. They renewed their contacts with Karol Estreicher, Tymon Terlecki, Kazimierz Lister, Feliks Topolski, the Themersons and Stanisława Dęborylska. Antoni Słonimski suggested possible cooperation with the monthly Nowa Polska, which he co-founded with Estreicher in $1942 .{ }^{12}$ Miłosz was looked after by the writer and activist of the international PEN-Club, Margaret Storm Jameson, who helped organize his meeting with T. S. Eliot. ${ }^{13}$ Correspondence from the years when Miłosz was trying to obtain an American visa confirms that the Nobel Prize winner did not forget him. We do not know the details of this, perhaps most important, meeting in London. That it was carefully planned, we know from the letter from Eliot's secretary of December 18. It came with an enclosed letter from Eliot, dated October 5, 1945, containing an authorization to publish the translation of The Waste Land free of charge.

The author of Rescue kept the image of England's capital in his mind. He wrote to Jerzy Andrzejewski: "The stay in London was the most pleasant part of our travels it's a very calm and soothing city, and we had plenty of friends, English and Polish" (Zaraz po wojnie [Right after the War], 31). He confided in the Zofia and Tadeusz Brezas: "Besides, the whole of London was something like a sanatorium - a very rural and quiet city, no round-ups;" "London seems to me almost like home, something like

\footnotetext{
Cambridge, Massachusetts \& London, England: The Belknap Press of Harvard University Press, 2017, p. 245 - also Emil Pasierski (Ibidem, pp. 194-195) uses this date, and February 7, 1946, is the date when, in his opinion, Miłosz took the post at the New York Consulate. As the correspondence with Jarosław Iwaszkiewicz shows, the Miłoszes may have left the country even later. See Czesław Miłosz, Jarosław Iwaszkiewicz. Portret podwójny [Czesław Miłosz, Jarosław Iwaszkiewicz. A Twofold Portrait]. Composed of letters, poems, intimate notes, interviews and publications. Selected, edited and arranged by Barbara Toruńczyk. Preparation and footnotes by Robert Papieski, Warsaw, 2011, p. 130. They were surely in London on December 10, as this is when the poet participated in the meeting of the British PEN Club in London - See Miłosz, Czesław: "Anglicy o Polsce i Polak o Anglii” [The English on Poland, and a Pole on England], Przekrój 1946, issue 44, p. 11. Miłosz's National Registration Temporary Identity Card, kept at the Beinecke Library, Box 181, Folder 2810, was issued with the date of December 11, 1945, whereas an immigration officer Clyde Ports confirmed his arrival in the USA on January 14, 1946.

12 In 1945 Miłosz published "Pożegnanie” [Farewell], Nowa Polska 1945, f. [fascicle] 3, pp. 132-133, and in 1946, "Przeżycie wojenne" [The War Experience], Nowa Polska 1946, f. 1, pp. 39-45, "Biedny chrześcijanin patrzy na rzeź w ghetcie" [A Poor Christian Looks at Slaughter in the Ghetto], "Portret z połowy XX wieku” [Mid-Twentieth-Century Portrait], Nowa Polska 1946, f. 3, pp. 145-146, "Granice sztuki (St. Ign. Witkiewicz z perspektywy wojennych przemian)” [Boundaries of Art (Stanisław Ignacy Witkiewicz from Perspective of Wartime Transformations)], Nowa Polska 1946, f. 4, pp. 209-224; “Granice sztuki (III)” [Boundaries of Art (III)], Nowa Polska 1946, f. 5, pp. 274-282.

13 Miłosz devotes a good deal of space to this in his article "Anglicy o Polsce i Polak o Anglii" [The English on Poland, and a Pole on England], op. cit., in which he gives an account of a meeting of the British PEN-Club.
} 
Zakopane or Podkowa Leśna - so quiet, pleasant, and peaceful” (Zaraz po wojnie, 525). ${ }^{14}$

Upon reaching Glasgow, the Miłoszes were supposed to sail to America on January 14. ${ }^{15}$ Eventually, they set off on January 16, onboard S.S. Elysia, to be welcomed twelve days later in New York by Alexander Hertz, a former colleague at Polish Radio. Once they were there, it turned out that the poet had been assigned to work at the General Consulate in New York.

\title{
In New York
}

The newcomers stopped at the Madison Square Hotel and then took a two-room apartment at 342 West $71^{\text {st }}$ Street in western Manhattan. The Consulate was located at 149-151 East 67th Street, in the east of the island. The fledgling cultural and press officer did not have time to familiarize himself with the new place. He jotted down his first impressions while still fresh. He wrote to the Brezas:

\begin{abstract}
Building such cities as New York is nonsense. The buildings are much too high; the stupid flashing of thousands of neon signs so dazzling, as I could discern, for visitors from Europe, is a cheap gimmick. If the slums of London are ugly, then here one sees kilometers upon kilometers of streets, compared with which Łódź is a miracle of beauty. Poverty and ugliness, garbage burning in the streets, cockroaches running around on top of drugstore counters, their little eyes casting inquisitive glances at the customer drinking milk. Few things compare with the sadness of these boroughs - the horror of a civilization leading nowhere (Zaraz po wojnie, 525).
\end{abstract}

One may wonder to what extent these sentences were a manifestation of culture shock, and to what a result of internalizing the European model of the city. ${ }^{16}$ The former resident of Wilno repeatedly complained about his difficulties in adapting to

14 In his first letters from England, Miłosz wrote "Someone may ask me, well, all right, but what about London itself? After all, it's such an enormous city, the whirl of cars, and buses, advertisements, the insane commotion of a large metropolis? Dear children, what of it? After experiencing the traffic on the bridge between Praga and left-bank Warsaw, London is like a large sanatorium in which the patient falls into the soft seats of the underground railway carriage, to emerge five minutes later at the other end of the city, in the fog of a dark street, where cats breed and some fellow walking his dog appears from time to time. The number of cars on the streets barely reaches 50 percent of the pre-war number. One does not see large luminous ads." In Miłosz, Czesław: "Anglicy o Polsce i Polak o Anglii” [The English on Poland, and a Pole on England], op. cit.

15 See Miłosz, Czesław: Letter to Aleksander Miłosz of January 10, 1946, Kwartalnik Artystyczny 2008, issue 3, p. 15.

16 Of note is the convergence in the images of Paris and New York in the works of Miłosz and Henry Miller, whose work the poet read in the USA. 
the climate, so he would leave New York whenever he could - in a letter to his father he described one such trip, to Rehoboth Beach, in the summer of $1946 .{ }^{17}$

He enjoyed resting by the ocean, in a cottage, in forest wilderness, without his New York obsession with confined spaces. He returned to his passion for ornithology there, and to his habit of swimming every day. He could not get enough of the abundance and exoticism of the local nature.

Miłosz started his work at the Consulate on February 7, 1946. His duties included

I. Informing the local community - both American and Polish - about the restoration of cultural and artistic life in the country.

II. Campaigning for material aid for Poland in the area of culture.

III. Informing the country about literary, artistic, and scientific life in the United States. ${ }^{18}$

Although - as he claimed later - efforts were made later to downplay his role, in accordance with the guidelines that Józef Winiewicz, the ambassador in Washington, was supposed to have received. ${ }^{19}$ When Miłosz began to serve, he undertook his work with energy, rapidly expanding his activities. He started by approaching the Polish diaspora. In the realities of post-war emigration, this was anexceedingly difficult task, as he confirms in the following report:

The new emigration is ex officio hostile to the Polish government; however, as a result of the inflow of information and the arrival of a number of people from the country, some opposition can be observed in this camp: voices saying it is impossible to feed the reader with fairy tales of Poland alone are beginning to emerge, and Lechoń, who knows no limit in his attacks, is being publicly criticized. (...) A number of people in the diaspora readily meet with me in private, but when asked to take part in some event, they openly say that they are afraid of local public opinion. I will note here that the fact that I came here as an official, not as a writer, complicates matters - for example, I encountered difficulties in organizing a contemporary Polish poetry evening. Several "neutral" people refused to participate, justifying themselves a thousand times that they simply cannot be seen together with consular officials. The most intellectually valuable

17 See Miłosz, Czesław: “Undated letter," Kwartalnik Artystyczny 2008, issue 3, pp. 18-19.

18 Sprawozdanie z czynności za okres kwiecień 1946. Czesław Miłosz, radca kulturalny Konsulatu Generalnego w Nowym Jorku [Activity Report for April 1946. Czesław Miłosz, Cultural Officer of the General Consulate in New York]. Archive of the Ministry of Foreign Affairs (henceforth: AMSZ), Department of the Press and Information (henceforth: DPI), collection (henceforth: c.) 21, bundle (henceforth: b.) 87, file 1186 (henceforth: f.)

19 See Winiewicz, Józef: Co pamiętam $z$ dhugiej drogi życia [What I Remember from my Long Path of Life], Poznan, 1985, p. 428. 
group of the new emigration is the Jewish intelligentsia, although even they are afraid to go too far in official cooperation..$^{20}$

The poet established and renewed contacts with Antoni Gronowicz, Antoni Marczyński, Marian Kistler, Mira Złotowska, Jakub Appenszlak, Władysław Malinowski, Ryszard Ordyński, Józef Wittlin, Aleksander Janta-Połczyński, Manfred Kridl, Ksawery Pruszyński, Ignacy Święcicki, Wacław Lednicki, among others, and met the local Polish community, including the Poles who served in the US Army. He started to cooperate with the Polish Club at Columbia University. He made efforts to get closer to the old emigration and the clergy - he met with Polish parish priests and monks on the East Coast. As he reported in April 1946, "It seems to me that the initial ice, as far as the Polish diaspora is concerned, has already been broken, and I am making a slow start in local circles, that is apart from the diehard Sanation circles of course. Undoubtedly, there is very strong interest in the cultural life of Poland, which is supported by magazines, public readings, and personal conversations." 21 He claimed that some of the priests in Massachusetts did not support the policy of the Polish American Congress; however - for fear of denunciation and accusation of favoring the communists - they would not reveal their views publicly. ${ }^{22}$

Miłosz's main task was the popularization of Polish culture in the USA. In March 1946, the bulletin of the Embassy Poland of Today featured his article about contemporary Polish literature, ${ }^{23}$ in April, one on the theater, and in October, one about the reception of American literature and art in Poland..$^{24}$ In spite of the unfavorable reactions of the Polish community, as he wrote in his report on April 27, 1946, he organized the first literary evening at the New York Public Library, under the patronage of the politically neutral Nasza Trybuna. It featured Manfred Kridl, Jakub Appenszlak, who spoke about Jewish-Polish literature, and himself, with a paper on the Polish literature of the wartime period and more recent works. To broaden the scope of possible activities, he approached the academic community: in the spring

20 Sprawozdanie z czynności za czas od 7 II 1946 r. - 30 III 1946 r. z dziahu kultury i sztuki - radca Czesław Mitosz, [Activity Report for the period between Feb. 7, 1946 and Mar. 30, 1946 from the Department of Culture and Art - Officer Czesław Miłosz] AMSZ, DPI, c. 21, b. 87, f. 1186.

21 Sprawozdanie z czynności za okres kwiecień 1946. Czesław Miłosz, radca kulturalny Konsulatu Generalnego w Nowym Yorku, [Activity Report in April 1946. Czesław Miłosz, Cultural Attaché of the General Consulate in New York]. AMSZ, DPI, c. 21, b. 87, f. 1186.

22 See Sprawozdanie z działalności za okres 15 VI - 15 VII 1946 r. Czesław Miłosz, attaché kulturalny Konsulatu Generalnego w New Yorku, [Activity report for the period from June 15 to July 15, 1946. Czesław Miłosz, cultural attaché of the General Consulate in New York]. AMSZ, DPI, c. 21, b. 87, f. 1186.

23 Miłosz, Czesław: "Literature in Poland Today", Poland of Today 1946, March, pp. 8-9.

24 Miłosz, Czesław: "American Authors and Their Polish Public," Poland of Today 1946, October, pp. 3-4. 
of 1946 he met with Christian Gauss, an expert on the poetry of Oscar Miłosz; he contacted Rutgers University Press, which was supposed to publish an anthology of international children's literature, as he wanted a Polish contribution to be included. He started work on an English-Polish and Polish-English dictionary, in consultation with Ernest Lilien. Further, he conducted campaigns to collect books and school supplies for Poland, and in cooperation with the École Libre des Hautes Études, he gathered a collection of documents on Polish-American relations in the eighteenth and nineteenth centuries.

As he emphasized later, he tried to avoid playing the double game (see Podróżny świata [A World Traveler], 70, Autoportret przekorny [A Contradictory Self-Portrait] 113). He did not play it in the political sense, although he was not indifferent to calls for help. In August 1946, Metody Suszkiewicz from Szczecinek asked for financial aid for a brother imprisoned in a Soviet labor camp in Siberia. ${ }^{25}$ Before the end of September, Suszkiewicz was thanking Miłosz for his letter of August 28 and for help ${ }^{26}$ - this shows that the poet was well aware of the realities of post-war Soviet labor camps. ${ }^{27}$

\section{"The Special Service of Keeping the Country Informed"}

Even though, as he claimed in his first letters, Miłosz did not miss Poland in a manner characteristic of the local emigration, he did go through crises of various origins. He was very slow to adapt to the climate and landscape of the East Coast - in his letter to Andrzejewski he called it a'wasteland' and this term coincided with sending his translation of Eliot's poem for publication in Poland. In time, he moved away from these initial impressions in favor of diagnoses, from observing the material in culture to learning and understanding the symbolic. His gradual shedding of preconceptions about the New World is evident in his letters touching

25 See the letter of Metody Suszkiewicz to Czesław Miłosz of August 17, 1946, Beinecke Library, Box 2, Folder 69, pp. 1-3. The poet commented on this later: "The absurd paperwork that piled up on my desk and the letter lying on top of it, from a camp near Archangelsk, was an outrage. The letter had been received in Poland by relatives of the prisoner and sent to me with the request for a package for him. I had to live with the image of camps and trainloads of prisoners heading toward them." (Native Realm, 297).

26 See the letter of Metody Suszkiewicz to Czesław Miłosz of September 28, 1946, Beinecke Library, Box 2, Folder 69, p. 2.

27 Ibidem, p. 3. Miłosz wrote in 1952: “Do you think that I don't know what happened in 1945? That I don't know what they did with members of the Home Army? Or what has been going on to this day in our native Lithuania? Do you think that I did not want to break off all ties in 1946, instantly after my arrival?” Letter of Czesław Miłosz to Melchior Wańkowicz, not dated. In Miłosz, Czesław, Wańkowicz, Melchior: Korespondencja 1951-1956 [Correspondence 1951-1956], Warsaw, 1986, p. 13. 
on metropolises, which Miłosz perceived ahistorically and described mainly by means of enumerations. In the initial period, he compared America and Europe; he verified the European myth of America acquired through cinema and reading. At the same time, he made extensive and concentrated efforts aimed at selfeducation, in keeping with his self-imposed rule of utility, and he began to see in work a form of self-treatment. Sensing the rising popularity of Poland, he asked for books he might recommend to local publishers, and for poems which might form an anthology of Polish poetry. He looked for works related to Poland, and works of authors unknown in Poland, such as Franciszek Andruszkiewicz, whose works he rewrote in the letters. He began cooperation with the PEN-Club and the United States International Book Association - in the first case regarding making a list of authors who needed support, in the second, about providing Polish libraries with materials via USIBA. At that time, Miłosz also gave a talk about Poland during the evening of the Kosciuszko Foundation, and he met Peggy Guggenheim, Thornton Wilder, and Dwight Ripley, a translator who had the intention of compiling an anthology of Polish poetry.

Miłosz kept the national community informed of artistic news from the West. His poetry from the time of the occupation gained fame in émigré circles - it was known in its Flemish translation - and its popularization in Brussels was the task of Józef Chudek and Marian Pankowski. Friends urged Miłosz to write a book about America, but he was still only gathering knowledge about the New World at the time. Realizing that the sum of his activities did not determine the value of his stay in America - he called them 'activités de surface.' In April 1946 he wrote to Andrzejewski: "I am striving to set up a special service to inform the country of the literary, artistic, and scientific life of America - I may succeed in this" (Zaraz po wojnie, 32). He sent his sketches about America, its culture and literature first to Kuźnica, ${ }^{28}$ Odrodzenie, ${ }^{29}$ and Przekrój, ${ }^{30}$ and then also to Nowiny Literackie and Twórczość. These texts also included translations of works in English. In 1946, under the pen-name Jan M. Nowak, he began the publication of a vast cycle Życie w USA [Life in the USA]. ${ }^{31}$ He also published in Poland under his own name, ${ }^{32}$ and later as Żagarysta. ${ }^{33}$ His plan of publishing an anthology of English poetry, which was

28 See Miłosz, Czesław: “O Hemingwayu” [On Hemingway], Kuźnica 1946, issue 38, pp. 5-7.

29 Miłosz, Czesław: “Massachusetts”, Odrodzenie 1946, issue 31, p. 6.

30 See Miłosz, Czesław: "Polska z Nowego Jorku” [Poland from New York City], Przekrój 1946, issue 66, pp. 7-8; Miłosz, Czesław: "Notatnik nowojorski” [The New York Notebook], Przekrój 1946, issue 79, p. 11.

31 See Nowak, J. M. [Miłosz, Czesław]: Życie w USA, Odrodzenie 1946, issues 51-52; Odrodzenie 1947, issues 1, 2, 7, 8, 9, 10, 11, 19, 21, 22, 25, 27, 30, 46, 47, 48.

32 See Miłosz, Czesław: “Na Independence Day” [For Independence Day], Odrodzenie 1947, issue 29, p. 5.

33 See Żagarysta [Miłosz, Czesław]: "Zabawy i spory” [Games and Arguments], Odrodzenie 1947, issue $44, \mathrm{p} .4$. 
prepared during the occupation, never came to fruition. For some unclear reasons, the entire venture stalled, and it proved impossible to resume it in later years. ${ }^{34}$

As he wrote in his report for the Ministry of Foreign Affairs, in 1946 he submitted at the Embassy a project of a newsletter which would provide the press and cultural and educational institutions in the country with artistic news - this initiative also passed unnoticed. In "Uwagi o pracy radców kulturalnych przy naszych placówkach w Stanach Zjednoczonych” [Notes on the Work of Cultural Officers at our Facilities in the United States], he recommended the expansion of libraries, asked for cultural magazines that he might pass on to the New York Public Library, and for photographs showing the reconstruction of Poland. He strongly advised the publication of an album featuring Poland - it was supposed to include photographs of children and young people, illustrating the country's development.

At the same time, the diplomat complained about censorship of letters and blocking of books sent from the USA. He warned, however, about allowing national magazines from Hearst Corporation to circulate: "The long-term gap in scholarly contacts, and ignorance of cultural processes abroad, lower the level of Polish works related to culture and, as in any other provincialism, lead either to exaggerated worship and mythologizing of American and English achievements or to their underestimation."35

Along with Teresa Żarnower, he sought reproductions of paintings from American museums and galleries for the public in Poland. His activities became ever wider, and they met with a vibrant response. Thanks to his contacts in cultural and scientific circles, he managed to expand cooperation with Smith College, Amherst College and Mount Holyoke College. This enabled the organization of English teachers' trips to Poland and contact with students involved in the theater movement - through them Miłosz intended to popularize the latest Polish drama. As part of university exchange, he wanted to bring his brother Andrzej to America - he persuaded him to learn English and participate in the scholarship competition. ${ }^{36}$

Regarding popularization of the theater, Miłosz communicated with Philip Drury from the United Nations Theater. Thanks to his Parisian contacts, he entered UN circles in New York in the hope of winning support for Polish-American cooperation. At the same time, he did not refuse to help those injured by the war. Requests for medicines, clothing, and food were sent to him from Poland, Great Britain, and Australia. What became of his shipments is evident from the correspondence.

34 See the letter of Tadeusz Breza to Czesław Miłosz of Sept. 18, 1946. Beinecke Library, Box 1, Folder 9. 35 Raport sytuacyjny o nastrojach na terenie działalności Konsulatu w New Yorku za okres 1 VI - 5 VIII [Situational Report on the Moods in the Area of Operations of the New York Consulate for the Period from June 1 to Aug. 5] AMSZ, DPI, c. 21, b. 81, f. 1182, p. 3.

36 See Miłosz, Czesław: Letter of April 6, 1946, Kwartalnik Artystyczny 2008, issue 3, pp. 16-17. 


\section{Representing the Consulate in the Region}

One of the first tokens of recognition for Miłosz's diplomatic abilities was his appointment as the secretary of the first session of the International Committee at the World Education Service. It was held on June 25, 1946. However, his activities also took on a more mundane form, for instance when, in cooperation with CARE, he demanded that the amount of fats in parcels sent to Poland be increased. In mid1946 he asserted: "We have already grown accustomed to America, which consists in realizing that for a European of a certain age, it is a country to which one simply cannot grow accustomed" (Zaraz po wojnie, 531).

The attaché continued to visit US and Polish-American institutions, giving lectures on history, culture, and literature. One of his most important speeches, "The Warsaw Ghetto Uprising” delivered in Boston, at the American Jewish Congress, also marked an anniversary. As the speaker himself recounted, he was greeted there reluctantly, as the Bund did not want to host a communist, but after a speech lasting about 40 minutes the reluctance toward him and toward the Poles subsided. The event was discussed at length in the local press: The Boston Globe, Boston Post, Boston Herald, The Jewish Advocate, Dorchester Record and The Congress News.

Miłosz took part in a number of similar events: on May 19 in New York he attended the meeting of the Jewish brotherhood of Zdunska Wola Society; on June 6 in Brooklyn, he gave a talk to the American Jewish Congress as a witness to the Ghetto Uprising; on June 12 he spoke again in Hartford, Connecticut. Responding to great interest in Polish-Jewish relations, as he wrote in his report, in 1947 he prepared an article on Auschwitz for Encyclopedia Americana. ${ }^{37}$ For the Embassy Bulletin Poland of Today, he submitted an article about the postwar situation of Polish writers, ${ }^{38}$ plus an introduction to a translation of an excerpt of Dymy nad Birkenau [Smoke over Birkenau. ${ }^{39}$ He tried to familiarize Americans with the Polish experience of the war - in letters he asked for books by Pola Gojawiczyńska, Seweryna Szmaglewska, Stanisław Dygat, and Tadeusz Breza, which he wanted to recommend to publishers. In 1946, he complained to the Brezas: "You have no idea what we must suffer here due to the idiotic anti-Jewish disturbances in Poland. The word Pole is slowly becoming synonymous with the word 'Nazi' and the commotion due to antisemitism in Poland is greater than due to Oranienburg and Auschwitz" (Zaraz po wojnie, 528). ${ }^{40}$ At the same time, however, he did not conceal from the Ministry

37 In the thirty-volume edition of Encyclopedia Americana of 1947 there is no entry by Miłosz.

38 Miłosz, Czesław: “Intellectual Revival in Post-War Poland”, Poland of Today 1947, April, pp. 7-8.

39 This text was not published in Poland of Today.

40 This problem was touched on by the Polish press. See Andrzejewski, Jerzy: "Zagadnienie polskiego antysemityzmu" [The issue of Polish Antisemitism], Odrodzenie 1946, issue 27, p. 4 and 
that after the pogrom in Kielce, it was no longer possible to give lectures about the Holocaust in Nazi-occupied Poland or the attitude of the Polish government towards Jews. ${ }^{41}$ This issue was touched on in the Resolution of the Chicago Branch of the American Federation of Polish Jews, published on June 16 in the New Herald Tribune:

\begin{abstract}
We, the delegates, gathered on June 16 at the Morrison Hotel at the 13th Annual Conference of the American Federation of Polish Jews, protest vehemently against the internal and external enemies of Poland who kill Jews on different pathways of time.

We ask the present Government of Poland to increase efforts to crush fascist elements that are not only enemies of Jews but also enemies of the present democratic Government.We ask the Government to arm Jews, so that they may defend themselves against the murderers. ${ }^{42}$
\end{abstract}

On 7 July, the American Polish League issued its own resolution on the matter - it was published by the New Herald Tribune on Sunday, July 14. In its wake appeared two articles by press correspondents - William Lawrence of The New York Times, and Homer Bigart of The New York Herald Tribune. In response, the Polish American Congress wrote: "The Communists want you to hate Poland. Only they are capable of such abhorrent means. Look at the bloody paws of the red bear and you will also see Jewish blood on them. We accuse the Bolshevik henchmen in Warsaw of having perpetrated this murder in Kielce!"43

Miłosz was unable to show any approval of the situation in his capacity of a regime official. Thus, in his private remarks, we find indirect complaints about the need to maintain mimicry. He took comfort in the thought that his stay in the US was only temporary. Despite the great distance, he considered himself very much a participant of the events taking place in Poland and in Europe. On the other hand, the American absence of an obligation to think always in historical terms was at least partly a relief. The poet more frequently availed himself of opportunities for recreation in the countryside, and often took sightseeing tours. Balancing the benefits and losses, over time he emphasized the significance of the benefits. In his letter to Breza, he expressed his hope of standing at some distance to Europe, Poland, and literature: "I think it was worth it anyway, because I am learning about the world better than I

issue 28, p. 3; Sartre, Jean-Paul: "Portret antysemity" [Portrait of the Antisemite], Nowiny Literackie 1947, issue 6, p. 1.

41 See Raport sytuacyjny o nastrojach na terenie działalności Konsulatu w New Yorku za okres 1 VI - 5 VIII [Situational Report on the Moods in the Area of Operations of the New York Consulate for the Period from June 1 to Aug. 5] AMSZ, DPI, c. 21, b. 81, f. 1182, p. 3.

42 Organizacje [Rezolucje: 1) Oddziału Chicagowskiego Amerykańskiej Federacji Żydów Polskich, 2) American Polish League. Oświadczenie Polish American Congress w New Herald Tribune: w sprawie pogromu Żydów w Kielcach] [Organizations [Resolutions: 1) Chicago Branch of the American Federation of Polish Jews, 2) American Polish League. Statement of the Polish-American Congress in New Herald Tribune: regarding the pogrom of Jews in Kielce] 1946, AMSZ, DPI, c. 21, b. 92, f. 1252. 43 Ibidem. 
would sitting in Krakow and, above all, I am learning to reject many interests in - or even respect for various human and literary phenomena - as sheer nonsense” (Zaraz po wojnie, 532).

\section{At the Polish Embassy in Washington}

On November 1, 1946, Miłosz was transferred to the Embassy, where he took the post of cultural attaché. ${ }^{44}$ His duties also included activities in the scholarly and cultural environment, and with dissemination of knowledge about post-war Poland. The diplomat continued his reports for the Ministry of Foreign Affairs, and his cooperation with literary magazines as a translator and columnist. ${ }^{45} \mathrm{He}$ also maintained cooperation with New York institutions and journalists: Gertrude Samuels of The New York Times Magazine, Isidor F. Stone of P.M., and Glenn Adams of The New York Times. At the invitation of Professor Arthur Coleman, he gave a lecture on contemporary Polish poetry at Columbia University and another, on the economic and political situation in the country, for the American-Polish intelligentsia at the Polish University Club in Newark. On November 22-23, in coordination with the Kosciuszko Foundation, he took part in the National Conference on International Education, working on the committee for books and for Central and Eastern Europe. A response from the Polish diaspora to the Foundation's contacts with Miłosz was swift to come. An account of the meeting to which he was officially invited, informed of:

The arrival of an UNINVITED representative of the Warsaw "consulate" at the lecture of professor Mierzwa, director of the Kosciuszko Foundation. (...) We do assure our readers, however, that in the future, should there ever be a shadow of cooperation between any Polish-American

44 Miłosz was a contractual employee of the Consulate until October 1946. By a decree of Aug. 22, 1946 he was appointed a full-time employee and cultural attaché. Czesław Mitosz's Personnel File, p. 5. 45 His tasks included:

"1. the general policy regarding cultural propaganda, in view of the special circumstances, one of the main means of expansion of our units in America

2. keeping the country informed

3. organization of large-scale events

4. contacts with the world of science and art

5. issues academic and student mobility

6. representing the Embassy in cultural matters (conferences, talks, etc.)."

After: Raporty propagandowe [Sprawozdanie Ambasady R.P. $w$ Waszyngtonie $z$ działalności informacyjno-kulturalnej polskich urzędów na terenie Stanów Zjednoczonych za rok 1948] [Propaganda Reports [A Report of the Polish Embassy on the Informational and Cultural Activities of Polish Institutions in the United States for the year 1948]], 1949 AMSZ, DPI, c. 21, b. 86, f. 1173. Cf. Leich, John Foster: “Only a Pole Could Have Been So Careless.” In Invisible Rope, p. 16. 
institution and Soviet-Warsaw agents in our area, we would warn both the Polish community and the American parties against this sort of trap, set by the regime in Warsaw. ${ }^{46}$

\section{Diplomatic Activity after the Election in Poland}

The relations between the embassy and the Polish community in America worsened after the falsified election to the Sejm. On January 19, 1947, groups of protesters demonstrated in front of the New York consulate, holding banners saying "We want American democracy in Poland. Democracy murdered today in Poland. Elections in Poland are not free. Poland today tomorrow America! Elections in Poland today are false [sic]." ${ }^{47}$ This undermined trust in the Embassy as a representative of the Polish state. Thus, propaganda activities were increased, authenticating the policy of the Warsaw government - in February Jerzy Borejsza announced his arrival in New York; in March he discussed with Miłosz the current opinions on Poland in the USA. ${ }^{48}$ These talks may have also referred to the plans for Miłosz's trip to Europe. In January, Breza urged him to return and edit a literary magazine with him - as he announced in the letter, he was going to talk to Borejsza about this matter. Miłosz, as it seems, preferred to maintain the status quo. In May 1947, evidently confused, Breza wrote the following:

I also wrote to you that I had urged Borejsza to bring you back to Poland and make you a member of some editorial office, at one of Czytelnik's ${ }^{49}$ magazines, living in a straddle between Poland and Paris. And Xawery told me that I was a fool to do so, because you are very pleased with America. I don't know anymore! I was sure that your eyes were firmly set on France. Especially since you've probably had enough of America by now (Zaraz po wojnie, 552-553).

The issue of staying in the West was becoming more and more problematic. Miłosz understood that a longer stay abroad excluded him from literary life in the country -

46 No author: "Na właściwej drodze" [On the Right Track], Nowy Świat December 5, 1946. After: Raporty prasowe [Przeglady prasy polskiej w USA sporzadzone przez Ambasadę R.P. w Waszyngtonie za okres od 22 stycznia 1946 do 17 listopada 1947 roku.] (1946-1947) [Press Reports [Reviews of the Polish Press in the USA Prepared by the Polish Embassy in Washington for the period from Jan. 22, 1946 to Nov. 17, 1947]] AMSZ, DPI, c. 21, b. 84, f. 1148.

47 Raporty Prasowe [Sprawozdania prasowe Konsulatu Generalnego R.P. w Nowym Yorku dotyczace spraw Polonii w Stanach Zjednoczonych, maj 1946 - luty 1948] [[Press Reports [Press Reports of the General Consulate of Poland in New York concerning Issues of the Polish Americans in the United States, May 1946 - Feb. 1948]], AMSZ, DPI, c. 21, b. 87, f. 1184.

48 In April of that year, Miłosz published the article "Intellectual Revival in Post-War Poland", Poland of Today 1947, April, pp. 7-8.

49 Czytelnik - a Polish publishing house established in 1944 by Jerzy Borejsza, moved to Warsaw in 1945. It organized bookstores and libraries and issued daily newspapers and magazines. It was a center of Polish culture, and was considered to be Jerzy Borejsza's “empire.” 
he kept receiving unsettling assessments of his poetry, which he tried to tackle in his correspondence. A friend of his reported a macabre April fool's joke to him:

You probably get a lot of clippings from the press concerning your spiritual side - a 'poet's profile.' A mention such as the one I attach here (Express Eódzki dated 29 March 47), treating only your mortal shell, you probably have not seen yet. It is also an omen, a portent of longevity.

\section{A Corpse in the Canal}

A corpse of a middle-aged man was found in the canal, which was flowing past property no. 249 in Wólczańska Street.

The Citizen's Militia was immediately alerted. Following the investigation, the deceased was identified to be Czesław Miłosz (34), residing at no. 3 Rzgowska Street.

The cause of Mr. Milosz's death has not yet been determined. The authorities are investigating the matter further, to determine if this was an accident, a suicide, or a crime. ${ }^{50}$

In Washington, Miłosz tried to establish new professional contacts: he solicited book donations for the National Library, coordinated academic exchange, organized film screenings, and collaborated with local radio stations that broadcast programs about Poland. At the beginning of 1947, he edited an article about Polish theater for the Hollywood newsletter Actors Laboratory, whose content largely coincided with the article on this subject for Poland of Today. He imported books for publishers interested in their translation for local distribution. He sought support for the teaching of Polish campaign at the Congress of Teachers of Slavonic and East Slavonic languages in Washington. He believed that the best way to provide knowledge about Poland was through presenting visual materials. He wrote to Wiktor Grosz:

(...) let me draw your attention to the value of artistic photography, which speaks in an international language and is easy to exploit in publishing houses. Among the materials we have received, some photographs of the ruins of Warsaw were marked by high artistic value, although they lost a good deal of their expression due to the quality of the prints. Most interesting here are the human figures, the "human document," the photographs we received could be graded $\mathrm{C}+$ at the most. The term "artistic photography" can be applied to works that arouse the viewer's interest with their perfect form, regardless of the subject, thanks to which the viewer becomes interested in the topic. ${ }^{51}$

50 Letter of Bolesław Bochwic to Czesław Miłosz of April 1, 1947. Beinecke Library, Box 1, Folder 6.

51 List Czesława Miłosza na ręce generała Wiktora Grosza w sprawie prac fotograficznych Ministerstwa Kultury. Propaganda [Notatka Cz. Mitosza - Attaché Kulturalnego Ambasady R.P. w Waszyngtonie dotycząca materiatów propagandowych otrzymanych $z$ Ministerstwa Kultury przez Ambasadę (fotografie, rysunki dzieci), (14 XI 1946 r.)] [Letter of Czesław Miłosz to General Wiktor Grosz regarding photographs of the Ministry of Culture. Propaganda [Memo of Czesław Miłosz - Cultural Attaché of 
In his letters, he suggested issuing a philatelic series about Poland. He continued his work of translation and popularization, and closely followed the course of literary life in the country. ${ }^{52}$ After moving to the capital, the scope of his duties increased, but so did the possibilities. In private, the Miłosz family treated the move as a necessary evil. The poet confessed to his brother:

I was appointed cultural attaché at the embassy in Washington, which entails a new move, and this is very cumbersome in a country where there are no apartments. Here in New York they charged us an arm and a leg, but otherwise an apartment could not be found; these bandits rent only to those who tacitly agree to cheat the rent control office. What I will find in Washington, I don't know. Washington is something like an enlarged version of Mokotów; the climate is as bad as in New York, but hotter, as it lies 400 kilometers to the south. However, we've grown accustomed to New York; we've got a lot of friends here and we're not very happy about this trip. All of our life on the move. In addition, Janka worked temporarily in New York, she will now have to quit. For now, I'm setting off for Washington to look for some home base. Here I had good working conditions, and I don't think I will have that there. I don't care about a diplomatic career and I console myself with the thought that the day will come when I can drop all of this to hell. ${ }^{53}$

At that time, Miłosz lived on the first floor of an air-conditioned house at 914 Sheridan Street, where a small garden was available - visible in the well-known photographs of the poet resting in a hammock, and with a book over coffee. The Embassy was located at $264016^{\text {th }}$ Street N.W. After the dark years of the occupation and "sincere rage" (to borrow Miłosz's own expression from the poem "Do Jonathana Swifta" [To Jonathan Swift], which accompanied him as he tried to settle in America, his comments from the beginning of 1947 seem to foretell a positive change. He confessed to Paweł Hertz: "America has brought back to me the taste of observing the phenomena of this world. My ambition has long been a certain internationality of mind, which, furthermore, protected me during the war" (Zaraz po wojnie, 497).

the Polish Embassy in Washington concerning propaganda materials received by the Embassy from the Ministry of Culture (photographs, children's' drawings), (Sept. 14 1946)], AMSZ, DPI, c. 21, b. 91, f. $1230, \mathrm{p} 1$.

52 In that year his translations of poems by Jorge Carrera Andrade were published, Nowiny Literackie 1947, issue 23, p. 3. The poet took part in the discussion "Jak oceniam literaturę dwudziestolecia?" [How Do I Asess the Literature in the Years 1918-1939], Twórczość 1947, issue 7-8, pp. 106-112 and "Czy wskrzesić Polską Akademię Literatury? Ankieta Odrodzenia" [Should the Polish Academy of Literature Be Restored? The Survey of Odrodzenie], Odrodzenie 1947, issue 13, p. 5. He wrote a review of films on war - "O kilku filmach" [On Several Films], Kuźnica 1947, issue 20, pp. 8-9.

53 Miłosz, Czesław: Letter to Andrzej Miłosz, not dated, Kwartalnik Artystyczny 2008, issue 3, p. 21. See also Miłosz, Czesław: Letter to Aleksander Miłosz, not dated, Kwartalnik Artystyczny 2008, issue 3, pp. 27-28. 


\section{Public Speaking Activities}

The diplomat still traveled around the East Coast giving talks and lectures to various audiences. On February 16, 1947, at the invitation of the Polonia Workers' Association in Detroit, he participated in the rally on the bicentenary of the birth of Tadeusz Kosciuszko and in honor of Abraham Lincoln. The journey was the probable inspiration for the poem "Detroit," which, on the advice of Tadeusz Juliusz Kroński, Miłosz did not publish at the time. On February 23 he visited Chicago, where he talked about the post-war transformation in Poland. On March 7, in the talk "Inner Experience of the European Writers" at Smith College in Northampton, Massachusetts, he discussed the significance of existentialism, Marxism and Catholicism in Poland and in Europe. ${ }^{54}$ At the end of March, at the Methodist Church in Washington, he spoke about Polish-American relations. On May 6, at the invitation of the Foreign Affairs Club, he gave a talk on the economic and cultural development of Poland at Massachusetts State College in Fort Devons near Boston. In it, he compared Poland to Greece, speaking of a "gentle revolution" over the Vistula. He met war veterans there, studying at the expense of the government, including 200 Poles, which the diplomat noted with great satisfaction. This trip was also an opportunity to visit Cambridge. Miłosz gave a similar speech on May 21, as he visited Fort Belvoir, a military center for convalescent veterans near Washington. During this time, the diplomat applied to UNRRA for help for Polish dentists, he organized student exchange, ${ }^{55}$ and made efforts to support Polish painters at the Museum of Modern Art. His activities did not subside when his son Antoni was born on March 29, 1947 in Washington. He organized short film screenings, concerts of music by Frédéric Chopin and Karol Szymanowski; he imported exhibitions of paintings, graphics and folk art, and took part in radio programs.

In the early spring of 1947, Miłosz held the additional function of press attaché. In the second half of March, he reported to the Ministry of Foreign Affairs about the significance of Harry Truman's speech, in which the President defined the priorities of the US foreign policy. He commented on activities directed against communists in state administration circles and Arthur Bliss Lane's resignation as ambassador. ${ }^{56}$ In April, his reports concerned the policy towards Germany and the possibility of establishing a union of European states in accordance with the idea of Winston Churchill, as well as American assessments of the internal situation in Poland. From

54 The text was translated into Portuguese and published in the literary periodical A Leitura in Rio de Janeiro.

55 In the Beinecke Library there is a letter of Alicja Iwańska, at the time a Ph.D. student at Columbia University, who made a request to Miłosz for help for herself and Henryk Hiż, studying at Harvard, (Box 1, Folder 27).

56 Miłosz never mentioned Lane's famous book I saw Poland Betrayed, New York: The Bobbs-Merrill Company, 1948, published upon his resignation from the post of ambassador. 
this period came the most critical press articles about the government - many articles against the recognition of Poland's western borders were published, and Poland itself was called a satellite of the Soviet Union, while negative evaluations of its policies significantly limited the Embassy's possible activities.

\section{An Exhibition of Polish Books in New York}

On May 3, an Exhibition "Postwar Poland 1945-47 - An Exhibition of Polish Books and Photographs." was opened at the New York Public Library. Efforts to prepare it had been made as early as December 1946. Regarding this, Ignacy Złotowski informed Alfred Berlstein in a letter that the Embassy received a collection of photographs featuring Poland's cities, towns and villages and their residents, the extent of postwar reconstruction, to illustrate the socioeconomic and cultural development of the country. In the name of the Embassy, he requested the use of a room or hall suitable for exhibiting about one hundred such photographs to show the American general public life and living conditions in contemporary Poland. In his response, Charles F. McCombs, at the time the librarian in charge of exhibitions, wrote that the library would consider a small exhibition of photographs from Poland, showing the country's progress in post-war reconstruction. He made the decision to go ahead contingent on seeing the photographs beforehand, and said that, while as many as one hundred photographs might not be shown, a significant selection could be displayed, along with Polish books and other materials on the rehabilitation effort. The tentative date of the exhibition was to be sometime in the early part of 1947, and the venue, the middle part of the second-floor hallway along Fifth Avenue - near the Slavonic Division. ${ }^{57}$ The exhibition showcased books issued by such publishers as Czytelnik, Książka i Wiedza, Trzaska, Ewert i Michalski, Gebethner i Wolff, Księgarnia św. Wojciecha, Państwowy Instytut Wydawniczy, Panteon, M. Arct, Kuthan and Swift. It included issues of magazines devoted to science, literature, and culture, as well as photographs, mostly from the Recovered Territories. The Library informed journalists of the official visit of Ambassador Winiewicz during the exhibition on Monday, June 16 at 2 p.m. at the New York Public Library. The Ambassador would be arriving in the company of Consul General Jan Galewicz, and Consul Tadeusz Kassern. He was to be greeted by Director of the Library Ralph A. Beals, accompanied by Dr. Avrahm Yarmolinsky, Head of the Slavonic Division, and Dr. Alfred Berlstein of the same Division. During the visit, Director Beals would officially thank Ambassador Winiewicz for a donation of 175 books, periodicals and photographs to the Library. The exhibition would

57 See Letter of Charles F. McCombs to Ignacy Złotowski of December 21, 1946. New York Public Library, Manuscripts and Archives Division, Lydenberg, Hopper and Beals Collection, Box 35, Folder: NYPL RD: Exhibitions Misc. 1946-1947. 
feature a survey of publishing in Poland after the war, and it would include fiction, poetry, children's literature, and works of non-fiction, all of which came from public and private donations to the Embassy. Journalists were notified of the exact location of the exhibition (the main corridor of the Central Building).$^{58}$ The exhibition and the visit were covered by the New York Herald Tribune: "It is a showing of books published in Poland since the German surrender (...)." 59 The exhibition was significant for the library itself, and for its Slavonic department, which was supplied with books and periodicals by the Ministry of Foreign Affairs and the Embassy. Avrahm Yarmolinsky assured the Embassy of his readiness to cooperate, develop, and popularize the Polish collection; ${ }^{60}$ he also urged the Ministry to donate new releases to the library. ${ }^{61}$ In July 1947, Winiewicz thanked Yarmolinsky for organizing the event and assured him the Embassy would continue in its efforts to provide the Public library with even more books and periodicals than before, and that indeed some materials for the library, addressed to Dr. Alexander Hertz, had already arrived at the Polish Consulate in New York. ${ }^{62}$ In Odrodzenie, Miłosz adds that the library received many inquiries about the Polish publishing movement. He estimated that the exhibition had been visited by seventeen to twenty thousand people - he himself encouraged journalists from P.M. to visit it, even though he did not blow his own horn about this in his correspondence. In the series $\dot{Z} y c i e$ w USA, he discussed its content and local reaction, but only from the perspective of the viewer, someone not involved in its preparation. Moreover, in the bulletin Poland of Today, there is a photo-reportage of Winiewicz's visit at the exhibition. In June 1947, the poet managed to invite the Quakers of Pendle Hill near Philadelphia to cooperate. The Quakers offered their help in transferring books to Poland.

58 See Note to City Editors. The New York Public Library, Manuscripts and Archives Division, Lydenberg, Hopper and Beals Collection, Box 36, Folder: NYPL RD: Exhibitions O-P.

59 The New York Herald Tribune, June 6, 1947.

60 See the letter of Avrahm Yarmolinsky do Józef Winiewicz of June 24, 1947. New York Public Library, Manuscripts and Archives Division, Lydenberg, Hopper and Beals Collection, Box 51, Folder: Poland 1934-1948.

61 See Letter of Avrahm Yarmolinsky to Wiktor Grosz of July 9, 1947. New York Public Library, Manuscripts and Archives Division, Lydenberg, Hopper and Beals Collection, Box 51, Folder: Poland 1934-1948.

62 See Letter of Józef Winiewicz to Avrahm Yarmolinsky of July 8, 1947. New York Public Library, Manuscripts and Archives Division, Lydenberg, Hopper and Beals Collection, Box 36, Folder: NYPL RD: Exhibitions O-P. 


\section{The American Garden of Science}

Shortly after settling in, Miłosz renewed his interest in nature; he was now able to spend more time outside the city, thanks to his newly obtained driver's license. He observed the changing seasons, discovered the hues, tones, and shades of the American countryside - he slowly built from these images a panorama of the East Coast, whose outline frames his American poems. He dreamed of writing an essay about the local trees and birds, which is why he studied textbooks on natural history as a source of knowledge and terminology. Although the idea never came to fruition, his letters mention sightseeing adventures very often. However, only from July 1 to July 31, 1947, did the poet enjoy an extended vacation at Hiram Camps on Cape Rosier in Maine. Nonetheless, even that trip did not bring him the peace he so desired.

Despite his duties in Washington, Miłosz read more and more. In his correspondence from 1947, he shared impressions from the novel Darkness at Noon. He was also interested in the American reception of Marxism. He soon went beyond the circles of American art, translating Chinese poets, black poets, and African American spirituals. He learned Spanish in order to translate the poems of Pablo Neruda. ${ }^{63}$ Proficiency in reading and translation pleased him all the more as it served his mission of being useful - this word appears in many of his letters. Complaining about boredom and excessive clerical work, Miłosz hoped to abandon the work of a diplomat and support himself solely by writing. He did not delude himself that such a thing would be realistic in the near future. He understood that if he had a chance to lead a life abroad, and he mentioned this possibility as early as 1947, he would be a translator rather than a poet. In America, as he quickly understood, it was the publicist, not the poet, that spoke to a wider audience. Moreover, he had to understand the different structure and hierarchy of the literary life in the US, and thus also agree to the lack of the romantic privileges that naturally came with being an artist in Poland. Apart from his unflattering opinion about the local reader of literature, an additional complication was his belief, expressed in 1948, that he would not be able to create in any language other than Polish. During this period, Miłosz understood the importance of all the roles in which he appeared publicly in the USA, at the same time being aware of their inadequacy, andhis own inability to perform other roles, better suited to his aspirations.

During the summer, the diplomat took part in a Writers' Conference, organized annually by Middlebury College in Bread Loaf, Vermont, which lasted from August 13

63 At that time, he published the first translations of Pablo Neruda's poems Odrodzenie 1947, issue 23, p. 10. As Zofia Nałkowska wrote, Miłosz met with Neruda at the theater during his stay in Poland in 1949. See Nałkowska, Zofia: Dzienniki 1945-1954. Część 2 (1949-1952) [Diaries 1945-1954. Part 2 (1949-1952)]. Preparation, introduction and commentary by Hanna Kirchner, Warsaw, 2000, vol. II, p. 107. 
to 28. He was the only representative of the world on the other side of the Iron Curtain, so he found himself having to correct opinions about Poles, Slavs and Europeans on multiple occasions. As he wrote in his report:

As the only European at the conference, I had to represent "Europe" in general, arguing as much for Polish literature, as for French theater, etc. Knowing the American environment, I avoided bringing Polish matters to the fore, treating Polish affairs as part of European affairs. Meeting a Polish writer seemed a surprise to many people, because in general American Poles are believed to be workers and farmers, and the existence of Polish intellectuals is doubtful for many people in American literary circles. ${ }^{64}$

Miłosz then entered the circle of New York intellectuals, about whom he wrote that they were:

very critical of the current American policy. (...) Politically, they sympathize mostly with Wallace, while finding it regrettable that Wallace is a non-serious and naïve figure. A strong anti-capitalist attitude, parallel with very critical attitudes towards Russian politics, is typical of this milieu. This environment fanatically supported Roosevelt's New Deal; now it is without leadership or assignment. $^{65}$

The poet maintained the relationship with Bread Loaf. He particularly wanted to disseminate war-related novels - he was persistent in seeking to have Dymy nad Birkenau [Smoke over Birkenau] translated and published. From October 30 to November 1, he participated in the convention of the Commission for International Educational Reconstruction in Washington D.C. to obtain book donations for the National Library, and scholarships for students and scholars.

\section{The Realities of the Cold War}

Undeterred by the progress of the Cold War, Miłosz became involved in activities for the development of Poland. He supported the reconstruction of the prehistoric Polish settlement of Biskupin, seeking support from the Rockefeller Foundation. He involved the Kellogg Foundation in helping Polish dentistry. His efforts did not bring the expected results, in part because Poland was being perceived with growing distrust.

I keep thinking about ways of bringing Polish writers here - we read in a letter to Iwaszkiewicz.

- Recently, I wrote a huge memorandum in this matter to the Commission for International

64 Raport z pobytu na Konferencji Pisarzy w Bread Loaf, Vermont w czasie od 13 VIII do 28 VIII 1947 [A Report on the Stay at the Writers' Conference in Bread Loaf, Vermont from Aug. 13, to Aug. 28, 1947] AMSZ, DPI, c. 21, b. 86, f. 1171, p. 2. Miłosz published an account of this conference was published under the pen-name Żagarysta in the article "Zabawy i spory" [Games and Arguments].

65 A report on the stay at the Writers' Conference in Bread Loaf, op. cit., p. 3. 
Reconstruction. In a few days, I will be meeting with the president of the Rockefeller Foundation - I'm going to pitch it to them, too. I am not losing hope, although there are two trends battling in the Americans when it comes to the east of Europe - a desire to show the newcomers what a beautiful place America is, and fear of the "reds." Slavs make them so disgusted [originally in English] that they cancel all programs in Polish on the radio, regardless of the political color (i.e. programs made by American Poles for the Polish community) (Zaraz po wojnie, 185).

Neither the Polish community, nor the policies of the Polish state were able to counteract these assessments or the difficulties resulting from them. The poet noticed not only the end of a boom for Polish literature that was harmful to Poland, but also the unfair stereotype of Slavs based on the psychological and cultural principle of grouping, which equated Russians with all other Slavs. In this situation, the poet enjoyed any signs of positive interest in Poland. In a report for the Ministry of Foreign Affairs, he discussed the success of the Warsaw Lives Again, exhibition which showed plans for rebuilding the capital, developed by Warsaw architects -Miłosz coordinated it himself on behalf of the Embassy. After success in Minneapolis, it was shown from October 9 to November 1, 1947 at the Architectural League of New York. It was graced by a lecture by Lewis Mumford - Miłosz never mentioned that he had the opportunity to meet him. He sent letters to Poland, in which he demanded that children's drawings, toys, pottery and folk crafts, photographs and reproductions of avant-garde painting be sent for propaganda purposes. He considered it necessary to educate teachers of Polish from the local diaspora in Poland, and to create language-related university majors for the needs of American Poles - he made efforts in this matter along with Stefan Mierzwa, president of the Kosciuszko Foundation.

The development of this cooperation was hindered by the US Information and Educational Exchange Act of January 27, 1948, which was one of the first manifestations of the Cold War in state policy. As Miłosz assessed:

The adoption of this bill [originally in English] is an important event in the history of the United States. It marks a new stage for a country which has not yet recognized the notion of official propaganda and endows the State Department's information service with a statutory basis, as well as legal grounds to request special funds for its operation. The main argument in the discussions was the organization of the British and Soviet services, and the need to oppose the latter was emphasized. ${ }^{66}$

\footnotetext{
66 Amerykańska shużba propagandowa na zagranicę (ref. Czesław Miłosz, Washington, Feb. 12, 1948) [American Propaganda Service for Abroad (prepared by Czesław Miłosz, Washington, Feb. 12, 1948)]. Propaganda [Amerykańska shużba propagandowa na zagranicę. Omówienie raportu Komisji Kongresu Stanów Zjednoczonych, sporządzone przez Czesława Miłosza - Attaché Kulturalnego Ambasady R.P. $w$ Waszyngtonie] [Propaganda [American Propaganda Service for Abroad. Discussion of the Report of the United States Congressional Committee, prepared by Czesław Miłosz - Cultural Attaché of the Polish Embassy in Washington], AMSZ, DPI, c. 21, b. 91, f. 1232, p. 1.
} 
The following figures illustrated the differences: the planned budget of information and cultural services for Poland provided for 58,362 dollars, and 732,000 dollars for Great Britain. The justification for allocating the funds in this way was that Poland is controlled by a "“Communist stooge clique'." 67

At that time, Miłosz had an established position in the intellectual milieu, which is why he continued to participate in the work of literary and university circles. From May 10 to 12, 1948, he participated in a conference on international student exchange at the University of Michigan in Ann Arbor. As he commented in his report:

The conference, like all American conferences, was prepared in an exemplary manner, with the time divided and allotted to the minute, and with a large amount of duplicated materials given to each participant. It was distinguished, as many American conferences, by an absolute lack of consideration of the essential issues, focusing instead solely on the technical details of student exchange. ${ }^{68}$

The attaché did, however, notice a change in the atmosphere surrounding academic exchange:

The 'increased vigilance' of the Emigration Office under pressure from the Congress is, as is easy to guess, directed against students with leftist beliefs, while a rather popular opinion (albeit not stated expressly at the conference) is that only communists are allowed to leave the countries of Eastern Europe. On the other hand, American universities fear students who may refuse to return to their countries, causing many problems to university authorities. ${ }^{69}$

\section{The Turn of 1948}

Despite the unfavorable conditions, after the winter of 1947 there was a breakthrough in Miłosz's life, which he confided in a letter to the Brezas dated May 16, 1948. He was now navigating with increasing ease in the multiracial and multiethnic environment, more easily identifying differences between the North and the South, the metropolis and the small town. He was using English not only to describe the things and phenomena that did not exist in Europe - he was delighted to find out how much the English language favors succinctness and economy of expression.

67 Ibidem, p. 3.

68 Wspótpraca intelektualna [Sprawozdanie Cz. Miłosza z konferencji w sprawie międzynarodowej wymiany studentów, 10-12 maja 1948 w University of Michigan], [Report of Czesław Miłosz from the Conference on International Exchange of Students, May 10-12, at the University of Michigan] 1948, AMSZ, DPI, c. 21, b. 83, f. 1131, p. 1.

69 Ibidem, p. 2. 
On April 1, he was appointed Second Secretary of the Embassy in Washington. He owed this promotion to this assessment of his work from January 28, 1948:

He is an outstanding employee of this unit and a real expert on cultural issues. He is not the clerical type and does require some supervision in team work - otherwise he easily breaks out of work routines. His shows a great aptitude for making contacts and speaking publicly. In the Polish work, he still needs be controlled due to his poetic ease of deviating from the particulars he is, however, improving every day. He is specially suited to the American area, but his interests are extensive. It seems to me that the use of his work depends most on the person of his superior, and with good management, Miłosz is a good employee in his area. ${ }^{70}$

In parallel, a letter of January 21, 1948 was sent to the Ministry of Foreign Affairs, requesting the promotion:

I confirm in the strongest possible terms that at the Polish Embassy in Washington, the position of attaché is of utmost importance and in this particular case, it does not require adepts, but rather highly qualified employees. ${ }^{71}$

His reports were rated very highly:

The reports prepared by Citizen Miłosz on cultural matters, and more recently his political elaborations, attest to his extraordinary diligence and mobility, high abilities, and high level of accomplishment. ${ }^{72}$

As Miłosz's work gained momentum, his activity brought results. The creation of the Adam Mickiewicz Department of Polish Culture at Columbia University contributed to strengthening his position. However, in July 1948 Kridl had to explain himself on account of his cooperation with Miłosz:

Since the establishment of the status quo in Poland, I believed that cooperation in the area of cultural affairs with institutions of the American government is not only advisable, but necessary; in truth, the only specific, positive work for the country that we can do here in foreign parts is aid [illegible word] clothing, food, etc., hence I cooperated with Mr. Miłosz with regard to scholarships for Polish students at US universities (we had two female students at Smith College), in providing books to Polish Universities, and clothing and food for students. From Smith College alone, dozens upon dozens of crates with such things have been passing through the Polish Consulate in New York, which also pays for their transport, and our Committee would

70 Czestaw Mitosz's Personnel File, p. 8.

71 Ibidem, p. 14. On March 8, 1948, a motion for a salary raise for Miłosz was submitted, and on April 5, 1948, the Ministry of Foreign Affairs received a letter requesting the issue of diplomatic passports for Miłosz and his wife, upon nomination to the post of Second Secretary of the Embassy. Czestaw Mitosz's Personnel File, p. 25.

72 Ibidem, p. 15. 
not have funds for it otherwise. Thanks to this official procedure, everything arrives intact. Can this sort of work be considered an act of national betrayal? ${ }^{73}$

Confirmation of these words came from Miłosz himself in an article from 1946 describing, among others, his official meeting with Kridl:

My stay here [in Massachusetts - E. K.] is filled with a range of visits paid to various professors, during which I am eloquent, witty, and vividly descriptive - doing anything I can to garner aid for Polish universities. (...) I am supposed to meet with good Miss Wilson, a professor of US history. Miss Wilson, dividing clothing for students of France, Italy, Greece and Poland, makes sure that Polish women get the warmest clothes: sweaters, sports shoes, fur coats, and warm underwear. Then I'm supposed to discuss the issues of books, scholarships, and lectures on Poland, and I hope to get a full set of publications for our botanical institutes. ${ }^{74}$

In 1950, the poet returned to the scandal surrounding the appointment of Kridl as the head of the Adam Mickiewicz Department of Polish Culture at Columbia University:

There are very strong cultural longings among the Polish diaspora, but satisfying them is by no means the goal of the Polish leaders. Regardless of their cunning and agility, the leaders can be said to be dim-witted people, and the influence they exert is a tragedy of the Polish emigration. Out of multiple examples, suffice it to mention but one: the action against the Adam Mickiewicz Department of Polish Culture, established at considerable cost and effort at Columbia University in New York on the 150th anniversary of Mickiewicz's birth. Professor Manfred Kridl, appointed by Columbia University as head of this department, was in numerous articles named "a dangerous Bolshevik" (?). A biting, damning argument against the Polish activists is the fact that they themselves have not thus far won the support for establishing a similar department in America, which, seeing that they act on behalf of "6 million Americans of Polish descent," requires no further commentary. ${ }^{75}$

Miłosz continued his series $\dot{Z} y c i e$ w USA and kept sending articles about culture in the United States to various periodicals, ${ }^{76}$ as well as translations of Pablo Neruda's poetry, a review of the anthology of French poetry by Adam Ważyk, ${ }^{77}$ and an outline of the work of William Faulkner. He worked on an English-language essay on Mickiewicz. Tadeusz Unkiewicz encouraged him to cooperate with the magazine Problemy [Issues] - Miłosz sent him scientific literature and wrote about American discoveries in

73 Letter of Manfred Kridl to unknown addressees of July 10, 1948. Manfred Kridl Collection. Columbia Rare Book and Manuscript Library, Box 3.

74 Miłosz, Czesław: "Massachusetts", Odrodzenie 1946, issue 31, p. 6.

75 Miłosz, Czesław: "Poeta-pieśniarz” [Poet-Bard], Kuźnica 1950 issue 5, p. 5.

76 See Miłosz, Czesław: "Książki i pisma w Stanach Zjednoczonych" [Books and Journals in the United States], Odrodzenie 1947, issue 6, pp. 1-3; "Abstrakcja i poszukiwania" [Abstraction and Searching], Odrodzenie 1947, issue 7, pp. 3-4.

77 Miłosz, Czesław: “Wiersze polsko-francuskie” [Polish-French Poems], Odrodzenie 1947, issue 37, p. 1. 
astrophysics. ${ }^{78}$ In the 4th issue of Twórczość his Traktat moralny [Treatise on Morals] was published..$^{79}$ Aleksander Janta-Połczyński referred to it, quoting fragments in his reportages first published in Kultura, and later collected in the book Wracam $z$ Polski [Returning from Poland]. ${ }^{80}$

In the spring of 1948, Miłosz coordinated the visit of Józefa Wnukowa, who brought with her an exhibition of contemporary Polish painting to the Kosciuszko Foundation. The Information Bulletin of the Library of Congress notes their joint visit. ${ }^{81}$ During her stay, he observed tensions between the Polish diaspora and the Foundation, which resulted in a poor reception for the exhibition.

As a regular guest of the Library, he made the acquaintance of its director, Luther Evans, active in UNESCO, and of Archibald MacLeish.

\section{Organization of the World Congress of Intellectuals in Defense of Peace in Wroclaw}

In September 1948, the diplomat organized a series of talks by Edmund Osmańczyk on the subject of Poland's Recovered Territories, but he was most devoted to preparations for the Congress of Wroclaw. Invitations to the event were sent to scholars, writers, artists, critics, and journalists. They mainly included sympathizers of Henry A. Wallace, supporters of the left, including those not necessarily supportive of the Progressive Party, struggling as it was for political relevance. Among others, Ruth Benedict and Randall Jarrell were invited. Some people were invited under code names; this group included the writer Herbert Agar, a supporter of Roosevelt's presidency, Samuel Bernstein, a historian of social movements, recommended by the left-wing magazine Science and Society, and Mervin Jules, a painter and art critic. Probably due to unfavorable voices about the Congress from the Polish diaspora press, organizational details and were kept secret, as wasthe exact list of guests.

78 See the Letter of Tadeusz Unkiewicz to Czesław Miłosz of Jan. 2, 1947 roku. Beinecke Library, Box 3, Folder 74.

79 It was officially commented on only by Jarosław Iwaszkiewicz and Bogdan Ostromęcki. See Ostromęcki, Bogdan: "Na marginesie pewnego traktatu moralnego" [On the Margins of a Certain Treatise on Morals], Dziś i Jutro 1948, issue 50, p. 4. More comments on this work are found in the correspondence of the time. Anna Kowalska writes: "In Polna [Street] we passionately read "Treatise on Morals,." Hardly any piece caused this much delight in some, and this much regret in Eleuterids." Letter of Anna Kowalska to Czesław Miłosz of Nov. 7, 1948. "Ale cóż ma począć poeta, jeśli nie może wyrażać litości i grozy?” Korespondencja Czesława Miłosza i Anny Kowalskiej z lat 1948-1950. ["What is a Poet to Do, Being Unable to Express either Pity or Horror?” The Correspondence between Czesław Miłosz and Anna Kowalska, 1948-50]. “Teksty Drugie” 2019, issue 3, p. 356.

80 See Janta-Połczyński, Aleksander: Wracam $z$ Polski [Returning from Poland]. Introduction and preparation by Grażyna Pomian, Paris-Krakow, 2013, pp. 171, 184, 188.

81 The Library of Congress Information Bulletin, May 25-31, 1948, p. 8. 
Although opinions of this initiative formulated in American papers were fairly neutral, it was generally believed that reaching an agreement in new political realities was impossible. In addition to renewing, developing, and establishing contacts in the scientific and journalistic milieu, Miłosz was tasked with convincing the most important writers to participate in the Congress. He tried to curb the appetite of his superiors for the arrival of authors of international renown like Steinbeck, Caldwell, Hemingway, Faulkner, Buck or Chagall.

Apart from the above people, the diplomatic service was counting on the participation of persons and organizations referred to in the reports as key contacts: One World Award Committee, the editorial team of Science and Society, Christian Gauss, the outstanding astronomer Harlow Shapley, a historian of literature from Harvard University Francis O. Matthiessen, Samuel Eliot Morison, a historian and sociologist at Harvard, well-known composer and musicologist Walter Piston, painter and sculptor Philip Evergood, economist Wesley Clair Mitchell, a renowned lawyer Robert R. Kenny, and Albert Einstein. It is not known how many of them Miłosz met in person, or with how many he communicated through the embassy. In the report, he only referred to the meeting with Einstein:

The visit (of the Ambassador and Cultural Attaché) [at Albert Einstein's] lasted two hours. He was very cordial. He spoke about the lack of freedom in America, because "he who has the power, begins to want to wield it" and the fact that, for example, atomic physicists are in practice prisoners of the state. He sympathizes with the Congress entirely and will write his address. He said that cannot help organizationally, because he knows nothing about it and does not deal with such things, "he usually just lends his name.” The conversation concerned, among others the importance of moral authority at the time when everything can be said of churches, except that that they have a moral authority. Einstein provided a whole series of tips, among others that trips directly to the Congress (with no connection to trips for other purposes and to other countries) would be impossible without a consent of the State Department. ${ }^{82}$

\section{Expositions of Wanda Telakowska's Exhibition}

Miłosz also helped Wanda Telakowska, who came to America with her exhibition of Polish folk art. It was shown after the Wroclaw Congress in ten cities in various states, including the Proctor Arts Institute in Utica, New York, the Butler Institute

82 Kongresy [Kongres wrocławski w 1948 r. Sprawozdanie Ambasady R.P. w Waszyngtonie z akcji przygotowawczej do Kongresu (ustalanie składu delegacji amerykańskiej). Sprawozdania z oddźwięków Kongresu na terenie Stanów Zjednoczonych], 1948, [Congresses [The Wroclaw Congress of 1948. A Report of the Polish Embassy in Washington regarding the Preparatory Activities for the Congress (decisions on the composition of the US delegation)] Reports on Reverberations of the Congress in the USA] AMSZ, DPI, c. 21, b. 92, f. 1254. 
in Youngstown, Ohio, the American British Art Center in New York, the New York Fine Arts Collection and the National Collection of Fine Arts in Washington, and in museums of the Smithsonian Institution. ${ }^{83}$ Miłosz made contact with galleries and museums, researched market demand, visited stores with folk art, and gathered knowledge about methods to document and archive folklore. Initially, the exhibition was met with a cold reception. After the failure of the Congress, cooperation between American institutions and communists was criticized. Polish art, accused of sterility and academism,was rated poorly. Finally, after overcoming the initial resistance in the museums, it achieved a degree of success, as attested by press reports in the Magazine of Art, The New York Times, The Evening Sun, The Art Digest, The New Yorker, New York Herald Tribune, Christian Science Monitor and Santa Barbra News-Press. As Miłosz summed it up, "This makes it much easier for us to work on other projects, and it is now the only counterweight to the extremely hostile political atmosphere." The exhibition coincided with the cinematic distribution of the film The Last Stage (Ostatni etap) and presentations of Andrzej Panufnik's Tragic Overture, which slightly improved the atmosphere around it.

Presentations of this collection required a good deal of traveling. At the end of May and early June 1948, Miłosz toured California: San Francisco, where he met with the painter Stefan Norblin, Los Angeles and Santa Barbra, where he visited the translator Tadeusz Skarżyński, Ganna Walska, Xenia Grzebieniowska, a friend of the Brezas and representative of the Embassy in California, as well as Mr. and Mrs. Tyszkiewicz. He also made attempts to reach Henry Miller. ${ }^{84}$ On account of the exhibition, Miłosz also visited Santa Fe, where he went with Wanda Telakowska to local museums and stores with Native American products. On the way back, the poet flew over the Grand Canyon. The landscape looked to him "as if on day two of the world's creation" (Zaraz po wojnie, 201), and this thought returned in his poems and essays written after 1960.

On June 12, 1948, a very flattering assessment of his activities was formulated:

1. Employee behavior: very good, shows professional reliability.

2. Professional qualifications and talents: a unique and brilliant intelligence. His cultural interests qualify him for the position of the Embassy's Cultural Attaché.

3. Results of previous work: Very good.

4. Usefulness of the employee in the region: Very high. Has established extensive cultural contacts.

5. Moral and political aspects: High ethical standards and extensive political interests; trustworthy.

83 See Wystawa polskiego przemyshu artystycznego i sztuki ludowej w Waszyngtonie 12 I - 31 I 1949 w National Collection of Fine Arts, [Exhibition of the Polish Industrial Design and Folk Art in Washington, Jan. 1 - Feb. 3 1949, National Collection of Fine Arts] AMSZ, DPI, c. 21, b. 87, f. 1174, p. 3.

84 At that time, Miłosz's essay was published under the pen-name Żagarysta, titled "Henry Miller, czyli dno” [Henry Miller or Rock Bottom], Odrodzenie 1948, issue 39, pp. 1-2. 
6. Prospects for development: His exceptional literary interests do not stand in the way of his development into an eminent diplomatic officer, provided that in further practice, he develops his organizational skills, which are still lacking. ${ }^{85}$

In the autumn of 1948, Miłosz carefully observed and commented in his reports on the press dispute surrounding the Adam Mickiewicz Department of Philology at Columbia University, chaired by Professor Manfred Kridl after the resignation of Arthur Coleman - he described the Polish diaspora pickets in New York and Chicago. Miłosz arrived in Chicago with Wanda Telakowska. There he talked to the Art Institute about the possibility of exhibiting her collection. Also there, on December 19, 1948, he gave a groundbreaking lecture on Adam Mickiewicz. ${ }^{86}$

\section{Creative Work after 1948}

With the start of 1948, the poet's reading, translation and essay writing begin to blossom - a demonstration of his impressive self-education effort, aimed mainly at strengthening his relationship with the Polish reader. Miłosz was invited to cooperate with Teatr magazine by Leon Schiller and the editorial team of Zeszyty Wrocławskie. Mieczysław Brahmer from the publishing house Czytelnik encouraged him to write a study of English-speaking poetry in the planned series Foreign Literatures. He wanted to use previously submitted materials for an anthology of English poetry and to include translations and sketches about Latin American art, but the project never came to fruition. He sent American literature to the country, to Maria Dąbrowska and Anna Kowalska among others - to her he sent short stories by William Saroyan and John Steinbeck. It was then that most of his poems, articles and translations were published in Kuźnica ${ }^{87}$, Odrodzenie, Nowiny Literackie ${ }^{88}$ and Twórczość. He

85 Czestaw Miłosz's Personnel File, p. 9. In that year Miłosz published his last article in the Embassy's bulletin - "Literature in Poland", Poland of Today 1948, August, pp. 7-8 and 16.

86 It became the basis for the later article "Mickiewicz and Modern Poetry", which the poet presented to various circles. It was rated very highly by Roman Jakobson, who, as may be gleaned from the letter of August 23, 1948, received a copy to read.

87 See Sandburg, Carl: "Przekłady Czesława Miłosza” [Works of Translation by Czesław Miłosz], Kuźnica 1948, issue 13-14, pp. 8-9.

88 Neruda, Pablo: "Oda do Federyka Garcia Lorca w przekładzie Czesława Miłosza” [Ode to Federico Garcia Lorca translated by Czesław Miłosz], Nowiny Literackie 1948, issue 18, p. 1; "Nowe przekłady Czesława Miłosza" [New Translations by Czesław Miłosz], Nowiny Literackie 1948, issue 4, p. 2; "Pablo Neruda. Pogrzeb na wschodzie w przekładzie Czesława Miłosza” ["Burial in the East” translated by Czesław Miłosz], Nowiny Literackie 1948, issue 3, p. 3; Miłosz, Czesław: "Notatnik" [The Notebook], Nowiny Literackie 1948, issue 8, p. 1 and issue 15, p. 1; Miłosz, Czesław: "Negro spirituals," Nowiny Literackie 1948, issue 26, p. 4; "Notatnik amerykański” [The American Notebook], Nowiny Literackie 1948, no. 40, pp. 1-2. 
wrote essays on Adam Mickiewicz, ${ }^{89}$ and on Jarosław Iwaszkiewicz's ${ }^{90}$ poetry. He encountered the books of literary criticism by Edmund Wilson. He translated a fragment of "The Wild Palms" and the short story "Red Leaves" by Faulkner. MobyDick made a great impression on him. He discovered Negro spirituals and argued:

the only living people (...) are Blacks and Indians - if you consider groups of people, not individuals. And thus the lowest, the poorest, the most disadvantaged. Mexicans, who live in mass at the level of Polish peasants, or even lower, are alive: they love, create art, fill the exhibition halls with crowds, from there the grand, leftist, political Mexican painting draws its juices (Zaraz po wojnie, 428).

In this tone, Miłosz wrote to many people. Reflecting, after many years, on the legitimacy of interpreting Neruda's poetry, he claimed that it was "part of the action against the barbarity" of Moscow (Zaraz po wojnie, 413), "as an antidote to the grayness coming from the East" (Zaraz po wojnie, 149). By providing translations of Negro spirituals, Neruda, or Chinese poetry, the poet could feel safe and, at the same time, have a sense of participating in a game with the authorities.

Nevertheless, many years later he asked himself:

To what extent was my sense of 'mission' self-deception? Surely, such a cure for pangs of one's conscience can be said to be of little more consequence than keeping one's fingers crossed. However, today, looking back on the decades of the People's Republic of Poland, one can admire the enormity of the work done by the writers of literature who played this game, and above all excellent translators of world classics, poetry, drama, novels, and essays (Zaraz po wojnie, 413).

The poet also looked for opportunities to publish his own books outside the domestic market. Starting in 1948, Miłosz would provide in his letters broader diagnoses of American culture, society and politics. Of note is also another fact: from this year on, he talked more and more about the New World from its own perspective. He acted as a mediator between cultures, without anticipating that this would be his role for the decades to come.

\section{Participation in the Conference for Peace}

Miłosz also played the role of an intermediary during the Cultural and Scientific Conference for World Peace, which took place from March 26 to 27 at the WaldorfAstoria hotel in New York. He looked after the Polish delegation, including Paweł

89 The article in question is "Mickiewicz and Modern Poetry", The American Slavic and East European Review 1948, issue 7, pp. 361-368.

90 Miłosz, Czesław: "Nad książką, czyli cudze chwalicie” [Over the Book, or the Grass is Always Greener], Odrodzenie 1948, issue 4, pp. 3-4. 
Hoffman, the editor of Kuźnica, Leon Kruczkowski and Stanisław Ossowski. The event was boycotted by the New York anti-Stalinist left. Under the guidance of Sidney Hook, it organized its own Congress of Intellectual Freedom. An active role in it was played by Dwight Macdonald, editor of politics, whom the poet approached earlier and to whom he - as he recalled in Inne abecadto [Further ABC's] - "owed much of his political education” (Inne abecadło, 204). Nowhere - except for the report for the Ministry of Foreign Affairs, displaying the alleged success of the venture ${ }^{91}$ - did Miłosz report on the conference, which took place in an atmosphere of scandal and was accompanied by a press war. ${ }^{92}$ This single example would be a testimony of Miłosz's consistent strategy of not disclosing the knowledge he gained and accumulated in America, and processed in later years. Alex Ross writes the following about the stormy deliberations at the Waldorf-Astoria hotel:

This was one of the first great propaganda battles in the cultural Cold War, and more than a few artistic reputations fell victim to the clash of ideologies. The martyr in chief was Dmitri Shostakovich, who had gone to America at Stalin's behest. Weird scenes surrounded Shostakovich from the moment he arrived on American soil. The Broadwood Hotel in Philadelphia canceled his dinner reservation on account of threats of violence. Demonstrators carried placards exhorting him to speak out or to defect (...) He read the speeches that were placed in front of him; he answered questions in accordance with instructions that were whispered in his ear. (...) Left-leaning American artists of all disciplines and persuasions gathered at the Waldorf to greet their Soviet counterparts. (...) Henry Wallace was there, and drew cheers as he entered. Time observed snidely that the event could have been mistaken for a Wallace rally. Clifford Odets, Lillian Hellman, and Arthur Miller also attended. Thomas Mann sent a message of support. (...) Most of the attendees did not know to what extent the event had been engineered by Soviet propagandists, who were under the aegis of the Cominform organization. Assembled on the other side of the political barricades was a coalition of disenchanted leftists who called themselves Americans for Intellectual Freedom. They holed up in the bridal suite at the Waldorf, trying to stem the tide of Communist and fellow-traveler propaganda. (...) The members of Americans for Intellectual Freedom fanned out to various speeches and panel discussions at the conference. (...) Several days later Life magazine opened fire on the entire world of Henry Wallace, the New Deal, the Popular Front, and the U.S. Communist Party. A sardonic photo essay on the Waldorf conference highlighted Wallace as the "standout fellow traveler," and a two-page photo gallery identified fifty "dupes and fellow travelers" who were said to be aiding the Communist cause. Copland, spelled "Copeland," appeared alongside Thomas Mann, Albert Einstein, Langston Hughes, Charles Chaplin, and all the above-mentioned attendees of the conference. Among

91 Sprawozdanie Czesława Mitosza z pobytu na Cultural and Scientific Conference for World Peace w Nowym Yorku w dniach 25-27 III 1949 r. [A report by Czesław Miłosz of his stay at the Cultural and Scientific Conference for World Peace in New York] Archiwum Akt Nowych, collection 237/XXII, file 553.

92 An extensive account of the conference was published as a four-page insert titled The Waldorf Conference attached to politics 1949, Winter. Miłosz also probably knew the article by Howe, Irving: “The Culture Conference,” Partisan Review 1949, May, Vol. XVI, No. 5, pp. 505-511. 
other things, Luce's attack indicated that the media's lionization of refugee intellectuals was at an end. A "strange rogue's gallery," Mann called the Life spread. ${ }^{93}$

Miłosz did not mention these events, nor was he asked about them in published conversations or extended interviews. The only person to ask him for a comment was Michael Wreszin, a Woodrow Wilson Fellow. The copy of the response to Wreszin's letter written in 1990 remains in the poet's archival collection.

\section{The Future and Its Dilemmas}

At the end of the 1940s, Miłosz understood better and better that a moment of choice was approaching. On April 18, 1948, he gave a bold lecture on Polish literature at Columbia University. After the Chicago lecture, the publication of Traktat moralny [Treatise on Morals] and press polemics with Jerzy Putrament, under the pen name Wincenty Bednarczuk, ${ }^{94}$ the lecture at Columbia may have worried his superiors all the more. Although Miłosz now moved much more freely in the American environment, he did not abandon his plans of returning to Europe, which resulted in disagreements with his wife. Miłosz even considered such improbable scenarios as joining the Primavera Hutterite community, members of which he met in Washington. ${ }^{95}$ His relations with the Polish community were still frosty - in letters he confessed his antipathy to some in the local environment, and he generally preferred to be in the company of Americans. Even though Jerzy Giedroyc (with the help of Aleksander Janta-Połczyński and Józef Czapski ${ }^{96}$ ) tried to encourage him to cooperate, the poet did not avail himself of this opportunity. For all his contacts, travels, and meetings with famous figures from the world of science and art, his sense of alienation did not abate. His attitude to the country was unequivocal, especially

93 Ross, Alex: The Rest is Noise. Listening to the Twentieth Century, pp. 406-411 in the 2007 Picador edition.

94 See Pasierski, Emil: op. cit., 202.

95 At the Beinecke Library there is a letter of Arnold Stevenson to Czesław Miłosz of May 9, 1949, along with extensive informational materials on the communities of Hutterites in Paraguay and England, Box 2, Folder 67. See also Miłosz, Czesław: “Primavera.” In Miłosz’s ABC’s. Translated from the Polish by Madeline G. Levine. New York: Farrar, Straus \& Giroux, 2001, pp. 224-225. The poet's correspondence shows that he paid a visit to Pendle Hill in 1947. See Letter of Czesław Miłosz to Thomas Merton, undated. In Striving towards being. The letters by Thomas Merton and Czeslaw Milosz. Edited by Robert Faggen, New York: Farrar, Straus \& Giroux, 1997, p. 59.

96 Czapski, announcing his arrival in Washington D.C., refers to an earlier conversation with Miłosz and finds him to be introverted. The letter implies the meeting with Miłosz did not pass easily. See the Letter of Józef Czapski to Czesław Miłosz of April 13, 1950. Beinecke Library, Box 1, Folder 15. The poet probably did not attend Czapski’s talk “Co widziałem w Rosji” [What I Saw in Russia] delivered in New York at the invitation of the Polish Institute of Sciences and Arts in America. 
after the publication of the poem "Toast (Poemat satyryczny)" [The Toast (A Satirical Poem)] in Odrodzenie. ${ }^{97}$ The poem did not go down well with editor Jerzy Giedroyc, and in Poland the attitude towards it was mixed. Miłosz complained to Józef Wittlin: “They performed an operation on my 'Toast.' They even went so far as to change the word 'Vlasovites' to 'Hitlerites'."98

Moderators of cultural life in Poland kept trying to get the poet to cooperate - he was asked for a chapter of a monograph about Stanisław Ignacy Witkiewicz. ${ }^{99}$ Miłosz himself did not abandon his intention to publish an anthology of English-language poetry in Poland - he urged Władysław Ryńca to have his translations published. ${ }^{100}$ Miłosz's uncertainty about his future in the West deepened, and his business trip to Poland gave it an additional coloring.

It is worth noting, however, that as one of the few poets, he praised JantaPołczyński's reportage Wracam $z$ Polski [Returning from Poland], ${ }^{101}$ in a situation when the reportage was rejected by part of the emigration. As Grażyna Pomian writes:

\footnotetext{
Most of the emigrants took Janta's reporting as a betrayal of independence ideals. Evidence of this was supposed to be Janta's alleged depiction of Polish citizens' acquiescence to the occupation by the USSR, and thus renunciation of independence, while the emigration deeply believed that the majority of the nation thought like them, rejecting the regime categorically, and awaiting the war that would liberate Poland. Criticism of Janta's reporting spilled to all continents where Polish émigrés were found. The most biting pieces - criticizing Janta along with Jerzy Giedroyc - appeared in Dziennik Polski i Dziennik Żotnierza. Both the reporter and the publisher were accused of undermining the "struggle for independence and integrity of the homeland," giving in to a system of violence imposed on Poland by the Yalta Conference." ${ }^{102}$
}

97 Miłosz, Czesław: “Toast (Poemat satyryczny)” [The Toast (A Satirical Poem)], Odrodzenie 1949, issue 16-17, p. 3 and 5. The deleted fragment was published in Kultura 1951, issue 5, pp. 14-15. Miłosz included remarks on censoring the poem in his letter to Wittlin of May 11, 1949, Miłosz, Czesław: " Z listów do Józefa Wittlina” [Excerpts from Letters to Józef Wittlin], Zeszyty Literackie 2001, issue 3.

98 Miłosz, Czesław: "Z listów do Józefa Wittlina” [Excerpts from Letters to Józef Wittlin], Zeszyty Literackie 2001, issue 3, p. 127.

99 See Letters of Jerzy Eugeniusz Płomieński to Czesław Miłosz. Beinecke Library, Box 2, Folder 58. 100 See the Letter of Władysław Ryńca to Czesław Miłosz of March 20, 1949. Beinecke Library, Box 2, Folder 63.

101 Janta-Połczyński's reportage appeared in installments in Kultura, but upon the intervention of General Anders Giedroyc stopped its publication, issuing it in whole as a book he himself financed See Janta-Połczyński, Aleksander: Wracam z Polski: Warszawa-Wrocław-Kraków-Poznań-Szczecinżycie-polityka-gospodarka-sztuka-ludzie i zagadnienia [Returning from Poland: Warsaw-WrocławKrakow-Poznań-Szczecin-Life-Politics-Economy-Art-People and Issues], Paris, 1949.

102 Pomian, Grażyna: "Awantura emigracyjna” [The Emigration Controversy]. In Janta-Połczyński, Aleksander: Wracam $z$ Polski [Returning from Poland]. Introduction and preparation by Grażyna Pomian, Paris-Krakow, 2013, p. 10. 


\section{On the Visit to Poland in 1949}

Miłosz left the United States on May 6, 1949. A day earlier the Ministry of Foreign Affairs received an encrypted message with instructions regarding his stay in Poland:

I am sending Miłosz to Warsaw, as per our conversations, for 10 days. Miłosz has not been in the country since 1946, and I am keen for him to refresh his impressions and meet with as many people as possible. He will bring an urgent package and discuss the details of cultural propaganda. ${ }^{103}$

According to the encrypted message of May 31, 1949, the diplomat's stay in Poland was to last until June $15,{ }^{104}$ but it was extended:

Regarding dispatch no. 584 from the American Department, I agree to extend Miłosz's stay, as I believe that it is very useful. In August, the month of holidays in the press, I am going to send you Jaworski. I expect to have Miłosz back here on July $10 .^{105}$

The poet reached Paris, where he met with Jerzy Putrament and Jarosław Iwaszkiewicz. On May 24, he arrived in Warsaw. Elsewhere in Poland, he visited his family in Sopot, then had an author's evening in Szczecin, where he met Andrzejewski. Then he went to Wroclaw - there he visited Anna Kowalska. In Katowice, he was present at the congress of the Association of Polish Visual Artists and at the Silesian State Theater, at the play As You Like It in his own translation, and in June in Krakow he met with Jerzy Turowicz and Tadeusz Różewicz. He also saw Wanda Telakowska, and then went to Olsztyn to visit his grandmother. From there he traveled to Warsaw, where he had the opportunity to meet Pablo Neruda in a theater, and at the Iwaszkiewiczes he talked to Zofia Nałkowska.

On July 4, he flew to Paris to give a lecture on the poetry of Oscar Miłosz at the Maison de la Penseé Française - at the reception at the Embassy he engaged in a discussion with Jules Supervielle and Louis Aragon. During his brief visit, he also managed to visit the Kroński family. On July 12, he flew to America, and after an emergency stopover in New Brunswick, he reached New York. The journey, which he called a "transplant" (Zaraz po wojnie, 230), gave him an opportunity to make new observations. His image of Paris had changed: "Paris has caused a sensation in me - its ineffable beauty and a complete shift of my attitude towards this city from my old times spent in it" (Zaraz po wojnie, 103); "Paris in July is so beautiful that it is breathtaking, but maybe it's too sweet, the human being probably needs more plain foods" (Zaraz po wojnie, 230). On the other hand, returning to America

103 Czesław Miłosz’s Personnel File, p. 24.

104 For this period, it was planned that Miłosz would receive a daily allowance. See Czesław Miłosz's Personnel File, p. 17.

105 Ibidem, p. 25. 
meant the necessity to re-adapt: "In fact, I was overwhelmed by these two months of travel and I had to adapt over again. In the end, in this country, if one wants to lead a European way of life, one might just go insane" (Zaraz po wojnie, 103). He wrote about the journey at greater length, and with more audacity, to Janta-Połczyński: "I left Poland impressed by the apocalyptic gravitas of the things that are happening there, and after Poland America now tastes completely bland." ${ }^{106}$ Franaszek adds: “On his return from Poland, the depth of Miłosz's estrangement from the new Polish status quo left him perplexed as to how he might extricate himself from what he increasingly saw as a distatesful situation." ${ }^{107}$ Probably after his July visit to the country, a decision was made to dismiss him from the function of secretary of the Embassy and bring him to France, where he would work under Putrament's supervision. ${ }^{108}$

\section{On Returning to Washington}

Despite of his sense of foreignness and irritation, Miłosz entered the New World more gently. On September 1, he reassumed his old duties and took what America had to offer in terms of culture: he began to celebrate American holidays, went to see exhibitions of paintings and posters in New York museums, finished his translation of Othello, frequented the cinema, and after buying a phonograph, started gathering a collection of records. In his letters, he described the celebrations of the centenary of Chopin's death at Carnegie Hall, preparations for the Year of Adam Mickiewicz and a volume of articles and essays on Mickiewicz. ${ }^{109}$

In his pragmatic assessment, Poland's participation in the meeting was free advertising of sorts, a form of a reminder that Wroclaw, Gdansk and Szczecin were Polish cities, thanks to which "the fact of the western borders is hammered home."110 To the editors of Masses and Mainstream, with whom he got acquainted more closely after the conference in Bread Loaf and the Congress of Intellectual Freedom, Miłosz gave Polish books: the prose of Zofia Nałkowska, Shakespeare by Adolf Rudnicki, and poems by Adam Ważyk and Tadeusz Różewicz. He urged correspondents to send in articles that the magazine agreed to accept also in Polish. He worked closely with

106 Letter of Czesław Miłosz to Aleksander Janta-Połczyński of July 12, 1950. The typescript is stored at the National Library, in the Archive of Aleksander Janta-Połczyński, call no. III 12 956, pp. 17-20.

107 Franaszek, Andrzej: op. cit., p. 271.

108 It was only on October 4, 1950 that Czesław Miłosz received a letter from the Minister of Foreign Affairs notifying him of his nomination to First Secretary for Cultural Affairs at the Polish Embassy in Paris, as of October 5, 1950. See Czesław Miłosz's Personnel File, p. 19.

109 This refers to a volume edited by Manfred Kridl: Adam Mickiewicz. Poet of Poland. A Symposium, New York, 1951, in which Miłosz published the essay "Mickiewicz and Modern Poetry".

110 Ibidem, p. 5. 
the national press, publishing poetry ${ }^{111}$ and translations of poems in Odrodzenie $e^{112}$ and Kuźnica. ${ }^{113}$ In the latter, he published an essay on Melville, which - after national cultural policy became more restricted in 1949 - was censored. ${ }^{114}$ Under the pseudonym Dr Pamfil, in Odrodzenie $e^{115}$ he defended the work of T. S. Eliot, who was attacked more and more violently after being awarded the Nobel Prize for literature. He reviewed the prose of Norman Mailer and William Gardner Smith. ${ }^{116}$ He offered editors subscriptions to Masses and Mainstream, Science and Society, and Saturday Review of Literature, and encouraged them to read New Foundations and Political Affairs. Hoffman wrote to him about the merger of Odrodzenie and Kuźnica, inviting him to cooperate with the resulting Nowa Kultura. ${ }^{117}$ His last translations printed before leaving the diplomatic service were fragments of Edward Gibbon's The History of the Decline and Fall of the Roman Empire, ${ }^{118}$ Othello, ${ }^{119}$ and poems of Chinese poets, ${ }^{120}$ and his last essays - "Obyczaje" [Customs], "O stanie poezji polskiej” [On the State of Polish Poetry] and "Poeta-pieśniarz" [Poet-Bard] on the work of Andruszkiewicz. ${ }^{121}$ His last poem the readers could read was titled "Żuławy" [The Fens of Zulawy]. ${ }^{122}$ On January 13, 1950, Miłosz wrote to Anna Kowalska:

The year is bad for me, and my heart is heavy - to put it shamelessly. I am translating Othello and besides, [I have] the feeling of a man with his arms and legs bound. I read a lot, for instance, I discovered that there is an ugly thing in the new literature - there is no place in it for translations of Jewish literature created in Poland, and you need to come to America to discover it. In addition,

111 Miłosz, Czesław: "Nowe wiersze" [New Poems], Odrodzenie 1949, issue 22, p. 1.

112 See Miłosz, Czesław: "Przekłady z poezji murzyńskiej” [Translations of African American Poetry], Odrodzenie 1949, issue 20, pp. 1-2.

113 See Ai Qing: "Człowiek który umarł drugi raz." Translated by Czesław Miłosz ["He Died the Second Time.” Translated by Czesław Miłosz], Kuźnica 1949, issue 19, pp. 8-9.

114 See Miłosz, Czesław: "Moby-Dick”, Kuźnica 1949, issue 6, p. 9. In his correspondence with Matuszewski, the author vehemently protested against shortening the essay in print (Zaraz po wojnie, 452 and 467).

115 See Dr Pamfil [Miłosz, Czesław]: “Awantura o nagrodę” [Controversy over an Award], Odrodzenie 1949, issue 39, p. 6.

116 Miłosz, Czesław: "Dwie książki o wojnie” [Two Books about the War], Odrodzenie 1949, issue 15, pp. 1-2.

117 Letter of Paweł Hoffman to Czesław Miłosz of March 14, 1950. Beinecke Library, Box 1, Folder 24. 118 Miłosz, Czesław: "Małe wypisy historyczne" [A Small Historical Reader], Nowa Kultura 1950, issue 20, p. 4.

119 Miłosz, Czesław: "Otello. Maur wenecki. Akt 1" [Othello. The Moor of Venice. Act 1], Twórczość 1950, issue 7, pp. 116-146.

120 Miłosz, Czesław: "Przekłady z poezji Chin Ludowych" [Translations from the Poetry of People’s China], Twórczość 1950, issue 9, pp. 83-86.

121 See Miłosz, Czesław: "Obyczaje” [Customs], op. cit.; "O stanie poezji polskiej” [On the State of Polish Poetry], Kuźnica 1950, issue 3, p. 3; "Poeta-pieśniarz” [Poet-Bard], Kuźnica 1950, issue 5, pp. 5-6.

122 Miłosz, Czesław: “Żuławy” [The Fens of Zulawy], Nowa Kultura 1950, issue 10, p. 8. 
I've become interested in automobiles, I go to a series of presentations of the history of film since 1903 (these are amazing things - a taste of half a century's worth of developments) and I go to the only theater in Washington, i.e. burlesque - another strange thing, nowhere to be seen outside of America: it is a representation of pure vulgarity, not even slightly colored by sentimentality, a kind of pornographic circus (and what else is Aristophanes' Lysistrata ultimately?) ${ }^{123}$

\section{In February 1950, he proposed publishing various works of translation and essays:}

1. A translation of Othello. Would an entire act fit in? Is Shakespeare palatable? It is not, in all fairness, an outstanding writer and his grandmothers were all wrong.

2. An essay about Shakespeare - mainly an analysis of the economic changes of his time and his life status - almost nothing has been written about it in Poland.

3. Translation of fairy tales (folklore) unknown in Poland. Folklore of Polish Jews? Blacks? Egyptians? (prose)

4. Free translations from ancient poets (but essentially according to the English translations).

5. Poems of my own - not much there for now.

6. Your own suggestions, Madam. ${ }^{124}$

As he recalled in Native Realm Miłosz became a regular at Washington's cinemas- he considered the dilemmas of returning to the past during the screenings of films he once saw in pre-war Wilno:

In the same month of January 1950, I attended a series of film screenings depicting the history of film from its beginnings. I saw the first German motion pictures, Life of an American Fireman (1903), fragments of other old American films, the German comedy Misunderstood (1912), short comedies by Chaplin, the comedy Male and Female (1919) directed by Cecil B. de Mille, starring Gloria Swanson, the German comedy Don Juan's Marriage (1919), and Cavaltanti’s Impressionist reportage from Paris Nothing but Time (1926). I also saw films particularly famous in the history of cinema: The Cabinet of Dr. Caligari (1919), directed by Robert Wiene, with Kraus, Veidt and Lil Dagover, The Italian Straw Hat (1927) directed by Réné Clair, with Préjean and The Passion of Joan of Arc (1929), with actress the [Renée Jeanne] Falconetti. ${ }^{125}$

In February 1950, the poet prepared an exhibition of children's paintings from Visual Arts and Culture Centers - he made a comment about them to Kowalska, saying they were better than many painted by adults he saw in the US. ${ }^{126}$

123 Letter of Czesław Miłosz to Anna Kowalska of January 13, 1950, op. cit., p. 357-358.

124 Letter of Czesław Miłosz to Anna Kowalska of February 15, 1950, op. cit., p. 361.

125 Miłosz, Czesław: "Obyczaje” [Customs], op. cit., p. 80.

126 Letter of Czesław Miłosz to Anna Kowalska of February 23, 1950, op. cit., p. 363. 


\section{How He Left the USA}

While Miłosz maintained his activités de surface, the decision to leave the USA grew stronger in him. His observations of the international scene, and the course of politics in Poland during his stay in the spring of 1949 turned his doubts into certainty, and his discomfort into suppressed fury, and despair. He confessed to Anna Kowalska:

I think a lot and I struggle. I cannot look at this country anymore - it's an insane asylum. However, the years of my stay in America have been decisive for me. In what way? - we have yet to see that. In any case, I have a great deal of knowledge about this country, and this knowledge is quite crushing. ${ }^{127}$

He sought help in making his decision from Saint-John Perse, Thornton Wilder and Albert Einstein. ${ }^{128}$ What happened next Miłosz describes in many places - uncertain as to his true viewpoints and intentions, Warsaw first lured Miłosz to Paris, ${ }^{129}$ so he might be brought back and ${ }^{130}$ kept in Poland. This proved difficult not only due to Miłosz's tactics of evasion - he wanted his wife to give birth to their second son in America (the first birth, by caesarean section, indicated possible complications in the future). In Warsaw, attempts were made to remedy this situation, as mentioned in the encrypted message of July 7, 1950:

127 Letter of Czesław Miłosz to Anna Kowalska of 1950, op. cit., p. 363. It is worth seeing this situation from a broader perspective, as does Tony Judt in the book Postwar. A History of Europe since 1945, which describes the terror of Stalinist purges and show trials in all of Central and Eastern Europe.

128 In his letter to Anna Kowalska, Miłosz considered publishing the poem "Do Einsteina" [To Einstein] in Zeszyty Wrocławskie. He added: "You would not like an ode to Einstein, whom I'm very proud to know in person. (...) He has just announced the crowning achievement of his life - equations providing the 'key to universe' demonstrating the identity of gravity and electromagnetism, i.e. providing the same explanation to the macrocosm and the microcosm. This is indeed a great century, as it sees the fulfillment of cabalistic expectations of the alchemists. My hidden second nature of the "sorcerer's apprentice" (without which it is not possible to practice poetry) is rejoicing. Letter of Czesław Miłosz to Anna Kowalska of Jan. 13, 1950, op. cit., p. 358-359.

129 This decision was not formally made at the Ministry of Foreign Affairs on February 7, 1950: “Czesław Miłosz - Second Secretary to the Embassy in Washington: 'A person who is entirely ideologically alien. After his last stay in Poland he revealed in his comments a decidedly hostile and denigrating attitude toward all aspects of life in the country. His wife - a bitter enemy of the Soviet Union. Call off - via Paris'.” After: Pasierski, Emil: op. cit., pp. 213-214.

130 Putrament recollected: "[Miłosz] also came to Warsaw. He came over to my place, as always, charming. We had a long conversation, which gave me the impression that everything in the country seems bizarre to him, if not downright hostile. That he is very far away from us. There was nothing particularly alarming about it, but when Berman called me several days later, he said that based on confidential information, they were afraid Miłosz may defect, and asked what I thought of keeping him in the country, and I admitted that there was probably no other way.” In Putrament, Jerzy: Pót wieku. Literaci [Half a Century. Men of Letters], Warsaw, 1986, p. 57. 
I inform you that M. received a letter from Putrament, announcing his transfer to Paris, and responded negatively. It can be expected that he will refuse to move even to Paris, because he is under the influence of his wife's early pregnancy and her belligerent moods. I suggest one more alternative: call him back to Warsaw to discuss his future, and stop him there. Then, of course, we risk that the wife will begin to scream at us over here. ${ }^{131}$

These predictions did not materialize, of which we learn from the cryptogram of July 13, 1950 which says:

I report that M. came to me and said that after consulting with his wife, he was not going to ask to extend their stay in the US in the event of his transfer to Paris.

I would like to point out that he knows from Putrament about the plan to transfer him.

I would like to remind you that you must now move him to Paris as soon as possible. Further:

1. I strongly advise that he be appointed a cultural adviser there.

2. Please formulate the telegram in such a way that I can hand it to him.

3. In the event of a dispute, I will put him on a plane to Warsaw to communicate with you directly. I shall be very pleased when the embassy is finally relieved of this burden of "Polish poetry." I am afraid of the effect of the mounting atmosphere of war on types such as this one. ${ }^{132}$

The negotiations were prolonged and took various turns. Originally the diplomat was to leave America on September 14, but this did not happen, as mentioned in the cryptogram of September 25, 1950:

Please be advised that on the 14th of August, Miłosz was supposed to leave. He approached me today with a request for a 2-week extension. I have concerns about his return. In conversations with him, one sees not only the fear of war, but also an unwaveringly hostile attitude towards the goals Poland is aiming for. He is trying to mask it with care for his family. I request information: To what extent do we care about Miłosz? Do we need to continue to handle him with kid gloves? Should I agree to postpone his date of departure, which still does not exclude further obstruction, one time it's his wife'spregnancy or a dental appointment, another time it's the war. ${ }^{133}$

Stalling for time, Miłosz made a request, which is reported in the cryptogram of September 21, 1950:

Justifying it with the opinion of the physician who found a pregnancy complication in Mrs. Miłosz, M. is asking for permission to let his wife stay here for about 4 weeks. M. wants to leave for Paris on Sept. 28. 1950, take office there, and go to Warsaw for talks with the Ministry of Foreign Affairs. We think that you should agree. Although the wife's condition is even dangerous, we think that:

M. does not want to break his ties with us.

131 Czesław Miłosz's Personnel File, p. 26.

132 Ibidem, p. 27.

133 Ibidem, p. 28. 
His wife refuses to travel, but she will break when her husband is in Paris. Otherwise, there may be undesirable complications here in the US. In addition, Miłosz's continued presence here, despite the dismissal, demoralizes the personnel in Washington. When Miłosz leaves, even without his wife, he will be removed from the staff list and his permit to stay will be revoked.

I request an immediate confirmation of our position, because it would be very detrimental to cancel the meeting with M., who should be leaving in one week. ${ }^{134}$

Eventually, the attaché left the United States on September 28, 1950, which was commented on in another cryptogram:

Today Miłosz is finally leaving. Please, make sure that they respond to him cordially in Paris and give him help in finding a flat. I ordered his wife be paid $\$ 300$ for October. M. asked me to pay for her an allowance until she gives birth. I replied that it was up to the Head Office and that I would support his request. I am of the opinion that we should agree and have some means of exerting pressure in this way. After a longer conversation with Miłosz, I am fairly optimistic about further development in this matter. ${ }^{135}$

On October 5, 1950, the Embassy was notified that he had arrived in Paris. ${ }^{136}$ Along the way, however, there was a misunderstanding:

Miłosz was informed by Słonimski that he was to become the director of the Polish Cultural Institute in London from April and that this matter was already agreed with the Headquarters. Give me an explanation.

Please, tell ambassador Wierbłowski. Miłosz is living in Duammont d'Urville and is happy with this because he has a nice room that costs him little. He wants to rent an apartment only for the arrival of his wife, i.e. in February or March, and he has seen some likely ones, but has refrained from looking further in view of the letter from Słonimski. ${ }^{137}$

As is well known, after Miłosz arrived in Warsaw, his diplomatic passport was taken away, which meant that he was forced to stay in Poland. Thanks to an extraordinary intervention from Minister Zygmunt Modzelewski on January 15, 1951, Miłosz departed for France. ${ }^{138}$ On February 1, he secretly left his official apartment, took refuge in Maisons-Laffitte, and then asked the French authorities to grant him political asylum. Warsaw was immediately informed about it:

134 Ibidem, p. 29.

135 Ibidem, p. 30. In the Beinecke Library, Box 181, Folder 2810 there is a certificate of nomination from the Ministry of Foreign Affairs, dated October 4, 1950, which names Miłosz First Secretary for Cultural Affairs at the Polish Embassy in Paris, as of October 5, 1950.

136 Czesław Mitosz's Personnel File, p. 31.

137 Ibidem, p. 32.

138 This is described at some length by Modzelewska, Natalia: "Miłosz w Polsce na przełomie 1950/51" [Miłosz in Poland at the turn of the year 1951], Kultura 1981, issue 3. 
Citz. OGRODZIŃSKI in telegram No. 171, dated 1.02.51 communicates that on Feb.1, 1951 in the morning, Miłosz left his flat, taking all the things he could take away by taxi. There is no doubt that he has deserted.

Citz. Ogrodziński asks for instructions as to whether he should try to contact him through citz. Grzędzielski and people close to the embassy from the world of culture, who know M. well, in order to try to agree with him on a peaceful breakup, with a promise from $\mathrm{M}$. that he will leave France and will not issue any statements to the press. ${ }^{139}$

Following this, he was dismissed from work on January 31, 1951. The consequences were felt by Janina Miłosz - in the cryptogram of February 12, 1951, we read:

Ambassador Winiewicz reports in telegram 69 from the $9^{\text {th }}$ of this month that apart from Voice of America, it is still quiet about Miłosz. Ambassador Winiewicz asks for information about his behavior in Paris after the desertion. He is concerned about the impact on the affairs of the Mickiewicz Institute. He asks to whom he should send the boxes containing the library that Miłosz kept at the embassy, which he thinks will be useful in Poland. Before the message from director Wilski, Mrs. Miłosz was only paid the hospital costs. Payment of $\$ 825$ for different medical costs was withheld. Nor did she receive the allowance for February. ${ }^{140}$

\section{The "Mitosz Case"}

If Miłosz's departure for the diplomatic posting was accompanied by various reactions in the country and abroad, his decision in February 1951 reverberated even more strongly. His resignation from the function of the First Secretary of the Polish Embassy in Paris, application for political asylum, and establishing close cooperation with Kultura grew into the 'Miłosz case,' although, as Renata Gorczyńska aptly put it, the 'Miłosz case' can be said to have started the moment he arrived in New York. ${ }^{141}$ In 1946, Dominik Horodyński wrote:

I wanted to visit you, Poet. I wanted to talk to you about Rescue. I kept looking for you, to no avail, until I was finally told you were gone - you had left the country - Natigoing away far and for long. (...) My goodness! - is it any wonder you had left? Nevertheless, you see, your departure in particular saddened me - saddened, but did not surprise. Because, clearly, it is better to be consistent in one's words and one's deeds, and your trip is a simple consequence of your book the only justifiable consequence of your attitude and your entire appraisal of what happened. In fact, the sole thing you could do was leave. Somehow, after all, one has to save one's own soul. ${ }^{142}$

139 Czesław Miłosz’s Personnel File, p. 33.

140 Ibidem, p. 34.

141 Gorczyńska, Renata: “Miłosza Ameryka dyplomacji, Ameryka imigracji” [Miłosz’s America of Diplomacy, America of imigration]. In Czesława Miłosza “pótnocna strona” [Czesław Miłosz’s Northern Side]. Edited by Małgorzata Czermińska, Katarzyna Szalewska, Gdansk, 2011, p. 246.

142 Horodyński, Dominik: “Gdzie ocalenie? Do Czesława Miłosza list otwarty” [Where Is the Rescue? 
Stefan Kisielewski, in Tygodnik Powszechny, echoed these sentiments. After 1951, those who did not speak publicly, reacted vividly in letters and diaries. Assessments of this decision also varied among his faithful readers. The poet repeatedly mentioned the circumstances of his trip and stay in the USA, without shying away from such assessments as this one:

From the beginning, my departure from Poland occurred under the sign of deception, because I was guided by a single desire: to leave. And then we shall see. Before her death, my mother simply ordered me to leave. Later, finding myself in America, I noticed that I had absolutely nothing to do there, in any sense at all. Aside from earning my living, along with "eating, defecating, and sleeping." My conflict with Kultura when I wound up there in 1951 - a conflict that may seem funny today but wasn't funny then - gives me some idea of the extent to which any integration at all into émigré circles was internally impossible for me (A Year of the Hunter, 212).

Miłosz repeatedly justified his decisions to accept and then leave the post of a diplomat. His subsequent statements were elaborated by further comments and explanatory remarks. They can be accounted for by a need to come clean, an attempt to understand; one can see in them an act of constructing his own biography, which the poet called "creative fabrication."

These attempts became more understandable when he started being referred to as a national bard. ${ }^{143}$ The moment of bringing his wife and sons to France closes the first period of being abroad; it is also the initial stage of Miłosz's many years of discovering America. To this day, this period of the Nobel Prize winner's activity and creativity has not been fully discussed. Perhaps a role here is played by the poet's own intimidating statements, as in A Year of the Hunter:

I have been thinking a lot about quite an important topic - about an examination of my stay in America from 1946 through 1950. More precisely, what America meant to me in those years. It was not what it is today, nor, I think, what it is for almost all of my contemporaries. Were I to try to ascertain this on the basis of my verse and prose writing from that period, I would not come to any unambiguous conclusions. I would characterize my situation as backbreaking, unbelievable, illogical, immoral, indescribable. After the passage of so many years, what I have managed to achieve in literature is projected backwards, the false game of those days is grounded ex post. At the same time, the historical phase loses its sharpness, and its most important features, perhaps, sink into oblivion (A Year of the Hunter, 116).

An Open Letter to Czesław Miłosz], Dziś i Jutro 1946, issue 8, p. 1.

143 See "Pamięć ran" [A Memory of Wounds]. A Conversation between Czesław Miłosz and Jerzy Turowicz, Rozmowy polskie 1979-1998 [Polish Discussions 1979-1998], pp. 33-43; Jarzębski, Jerzy: “Być wieszczem” [To Be a Bard], In Poznawanie Miłosza 2. Part Two (1980-1998) [Appreciating Miłosz 2]. Edited by Aleksander Fiut, Krakow, 2001, pp. 102-124. 